Aitor Alonso-González, Emma Orive*, Helena David, Koldo García-Etxebarria, José Luis Garrido, Aitor Laza-Martínez and Sergio Seoane

\title{
Scaly green flagellates from Spanish Atlantic coastal waters: molecular, ultrastructural and pigment analyses
}

\begin{abstract}
Seven scale-bearing species of prasinophyceans (Chlorophyta) were studied in light and electron microscopy, pigment analysis, and molecular analysis of the small subunit (SSU) rDNA. Unialgal cultures were obtained from samples collected in the Nervión River estuary, Gulf of Biscay, Spanish Atlantic coast. Five of the species belong to the genus Pyramimonas (Prasinophyceae, Pyramimonaceae) and one each to the genera Mamiella (Mamiellophyceae, Mamiellaceae) and Nephroselmis (Nephroselmidophyceae, Nephroselmidaceae). The morphological features of all the strains analyzed agreed closely with the phylogenetic analysis, which in the case of the genus Pyramimonas presented several clusters corresponding to the subgenera Vestigifera (Pyramimonas orientalis, Pyramimonas moestrupii), Punctatae (Pyramimonas robusta), Pyramimonas (Pyramimonas propulsa), and Trichocystis (Pyramimonas grossii). Even though the phylogenetic relationship among these subgenera remains unclear, the results suggested that the Punctatae should remain an independent clade at least until more sequences or genes are analyzed. According to their accessory pigment composition, three groups were distinguished after their pigment ratios were calculated: prasinoxanthin-containing (Mamiella gilva), loroxanthin ester-containing (P. grossii and P. moestrupii), and siphonaxanthin-containing strains (Nephroselmis pyriformis and remaining Pyramimonas species). A high intraspecific
\end{abstract}

*Corresponding author: Emma Orive, Faculty of Science and Technology, Department of Plant Biology and Ecology, University of the Basque Country (UPV/EHU), 48940 Leioa, Spain,

e-mail: emma.orive@ehu.es

Aitor Alonso-González, Helena David, Aitor Laza-Martínez and Sergio Seoane: Faculty of Science and Technology, Department of Plant Biology and Ecology, University of the Basque Country (UPV/ EHU), 48940 Leioa, Spain

Koldo García-Etxebarria: Faculty of Science and Technology, Department of Genetic, Physical Anthropology and Animal Physiology, University of the Basque Country (UPV/EHU), 48940 Leioa, Spain

José Luis Garrido: CSIC, Instituto de Investigaciones Marinas, Vigo 36208, Spain variability was found, which highlights the need of an indepth analysis and multiple technique approach to ensure accurate identification of nanoplanktonic microalgae.

Keywords: estuary; Gulf of Biscay; molecular analysis; morphology; scale-bearing prasinophyceans.

DOI 10.1515/bot-2013-0108

Received 7 December, 2013; accepted 5 August, 2014; online first 4 September, 2014

\section{Introduction}

Coastal embayments are nutrient-rich areas where marine phytoplankton can grow faster than in offshore waters. Although river inputs can be considered as small during part of the year relative to the total volume of water contained in embayments, these areas receive a constant supply of nutrients, which makes phytoplankton blooms a common feature (Ianson et al. 2001).

The Nervión River estuary drains into the Atlantic side of the Iberian Peninsula in northern Spain. During the last decade, it has been the subject of several monitoring programs covering a broad range of physical and biological variables, including phytoplankton composition and abundance (García-Barcina et al. 2006, Garmendia et al. 2011). Pigment analysis using high-performance liquid chromatography (HPLC) has revealed the predominance of fucoxanthin-containing algae, followed by alloxanthin- and chlorophyll $b$-containing algae, while peridinin represented a small fraction of the total chlorophyll $a$ (Seoane et al. 2006, Laza-Martínez et al. 2007). A taxonomic characterization of diatoms, haptophytes, and cryptophytes has been conducted and the main blooming taxa identified (Seoane et al. 2009a,b, Orive et al. 2010, Laza-Martínez 2012, Laza-Martínez et al. 2012). However, the taxonomic composition of chlorophyll $b$-containing algae is poorly understood despite their high contribution to the phytoplankton biomass. 
Phytoplankton abundance has revealed the predominance of the genera Pyramimonas Schmarda and Tetraselmis F. Stein in the Nervión River estuary (Seoane et al. 2005 , 2006), although for accurate identification of these genera and other scale-bearing chlorophytes, various approaches proved necessary, including electron microscopy, molecular and pigment analyses. The cells and flagella of Pyramimonas species are covered with several types of organic scales, which generally enable these flagellates to be accurately identified at the species level. Most descriptions are thus based on electron microscopy of the body scales plus ultrastructural analyses of the cell, including thin sections of pyrenoids and eyespots (McFadden et al. 1982, Daugbjerg and Moestrup 1993, Pienaar and Sym 1997, Daugbjerg 2000, Suda 2003). Although the presence of cryptic species is not a common feature in these scale-bearing flagellates, molecular analysis of nuclearencoded rDNA and plastid-encoded DNA sequences are very useful to supplement morphological identification and gain insight into the phylogenetic relationships between different taxa (Moro et al.2002, Suda 2004, Marin and Melkonian 2010, Faria et al. 2011, 2012, Yamaguchi et al. 2011). On the other hand, various accessory pigments are known to be characteristic of the prasinophytes (e.g., prasinoxanthin, siphonaxanthin, loroxanthin), and a considerable effort has been made to identify signature pigments or suites of pigments (Egeland et al. 1997, 2011, Latasa et al. 2004, Seoane et al. 2005, 2006, 2009a, LazaMartínez et al. 2007, Garrido et al. 2009). As a result of these efforts, pigment analysis has been established as a valuable complementary tool for taxonomical studies.
Consequently, the main goal of this study is to contribute to the knowledge of the scale-bearing prasinophytes of an estuarine area where chlorophyll $b$ accounts for a considerable proportion of the total phytoplankton biomass by studying these microalgae using morphological, molecular, and pigment analyses.

\section{Materials and methods}

\section{Strain isolation and culture conditions}

Surface water samples were collected with a bucket thrown from the deck of a small ship between 2006 and 2008 in the Nervión River estuary ( $43^{\circ} 20^{\prime} \mathrm{N}, 2^{\circ} 70^{\prime}$ W), northern Spain. All 13 strains analyzed in this study were isolated from crude multialgal cultures mainly collected from the Nervión River estuary, but also from occasional sampling from the port of Zierbana ( $\left.43^{\circ} 21^{\prime} \mathrm{N}, 3^{\circ} 4^{\prime} \mathrm{W}\right)$, the Urdaibai Estuary $\left(43^{\circ} 22^{\prime}\right.$ $\left.\mathrm{N}, 2^{\circ} 40^{\prime} \mathrm{W}\right)$, the marina of Getxo $\left(43^{\circ} 20^{\prime} \mathrm{N}, 3^{\circ} 01^{\prime} \mathrm{W}\right)$, and the Nervión River estuary, itself (strains CGA12 and CGA13) (Table 1). Microalgae were isolated individually by pipetting single cells directly under the inverted microscope (Nikon Eclipse TE2000-U). For additional information on the study area and sampling methods, see Laza-Martínez et al. (2007). All cultures were grown in $\mathrm{f} / 2$ medium (Guillard and Ryther 1962$)$ at $17^{\circ} \mathrm{C}$, an irradiance of $30-80 \mu \mathrm{mol}$ photons $\mathrm{m}^{-2} \mathrm{~s}^{-1}$ and under a 14:10 $\mathrm{h}$ or 12:12 $\mathrm{h}$ light:dark regime.

The serial dilution culture method (Throndsen 1978) was employed to establish crude cultures, with three

Table 1 Strains of prasinophytes isolated from the Nervión River estuary and nearby collecting sites sampled during 2005 and 2008 , with salinity of the cultures.

\begin{tabular}{|c|c|c|c|c|}
\hline Strain & Taxon & Location & Date & Salinity \\
\hline CGA09N.C. & Pyramimonas orientalis & Urdaibai Estuary, Vizcaya, Spain & 26 May 2006 & 30 \\
\hline CGA12 & Pyramimonas orientalis & Nervión River estuary, Outer Abra & 4 Oct. 2008 & 30 \\
\hline CGA13 & Pyramimonas orientalis & Nervión River estuary, Outer Abra & 4 Oct. 2008 & 30 \\
\hline CGA14 & Pyramimonas orientalis & $\begin{array}{l}\text { Nervión River estuary, Station } 2 \\
\left(43^{\circ} 20.3712^{\prime} \mathrm{N}, 3^{\circ} 01.8200^{\prime} \mathrm{W}\right)\end{array}$ & 17 Sep. 2008 & 30 \\
\hline CGA10 N.C. & Pyramimonas moestrupii & Nervión River estuary, Station 0 & 4 Jul. 2006 & 35 \\
\hline CGA11 $1^{\text {N.C. }}$ & Pyramimonas grossii & $\begin{array}{l}\text { Nervión River estuary, Station } 1 \\
\left(43^{\circ} 20.8865^{\prime} \mathrm{N}, 3^{\circ} 01.5295^{\prime} \mathrm{W}\right)\end{array}$ & 12 Mar. 2007 & 30 \\
\hline CGA15 & Pyramimonas robusta & Nervión River estuary, Station 2 & 17 Sep. 2008 & 30 \\
\hline CGA16 ${ }^{\text {N.C. }}$ & Pyramimonas propulsa & Nervión River estuary, Station 1 & 29 Aug. 2006 & 30 \\
\hline CGA06 & Mamiella gilva & Port of Zierbana, Vizcaya, Spain & 16 Sep. 2007 & 35 \\
\hline CGA07 $7^{\text {N.C. }}$ & Nephroselmis pyriformis & Nervión River estuary, Station 0 & 4 Jul. 2006 & 35 \\
\hline CGA08 ${ }^{\text {N.C. }}$ & Nephroselmis pyriformis & Nervión River estuary, Station 2 & 12 Mar. 2007 & 30 \\
\hline CGA17 ${ }^{a}$ & Oltmannsiellopsis unicellularis & Marina of Getxo, Vizcaya, Spain & 30 Aug. 2005 & 30 \\
\hline CGA19a & Oltmannsiellopsis unicellularis & Marina of Getxo, Vizcaya, Spain & 7 Jun. 2008 & 30 \\
\hline
\end{tabular}

N.C., nonclonal strain subcultured to achieve clonal strain by micropipetting. ${ }^{\text {SStrain }}$ used as outgroup for the phylogenetic analyses. 
dilution steps of 1:10 and three replicates of each dilution stage. Afterwards, the original inocula for unialgal cultures were obtained from those cultures by mouth pipetting.

\section{Light microscopy (LM)}

The morphological characteristics of prasinophyte cells were examined using a Leica DMRB microscope (Leica Microsystems, GmbH, Wetzlar, Germany) equipped with phase contrast and epifluorescence optics, and photomicrographs were taken with a Nikon DS-U2 camera (Nikon Corporation, Tokyo, Japan).

A solution of SeaPrep ${ }^{\circledR}$ Agarose (Lonza Rockland Inc., Rockland, USA) was used to slow down the movement of prasinophyte cells in order to make it easier for taking photomicrographs (Reize and Melkonian 1989). For the examination of pyrenoids and starch deposits in prasinophyceans, cells were stained with azocarmine G (SigmaAldrich, Madrid, Spain). A volume of the culture was fixed with $0.5 \%$ glutaraldehyde solution (Sigma-Aldrich) for at least $10 \mathrm{~min}$, then subsequently filtered through a 3- $\mu \mathrm{m}$ pore size polytetrafluorethylene (PTFE) filter (Osmonics Sdn. Bhd., Penang, Malaysia), and washed over the filter with culture medium at the same salinity as the culture. Subsequently, the filter was covered with an azocarmine $\mathrm{G}$ solution consisting of $5 \mathrm{~g}$ of azocarmine $\mathrm{G}$ dissolved in $65 \mathrm{ml}$ of boiling distilled water, to which $45 \mathrm{ml}$ of glacial acetic acid was added once the mixture reached ambient temperature. Thus, the solution was filtered through 3-, 1- and 0.2- $\mu \mathrm{m}$ pore size PTFE before use. Filters covered with azocarmine $\mathrm{G}$ solution were left at $50^{\circ} \mathrm{C}$ for $30 \mathrm{~min}$ and then at $37^{\circ} \mathrm{C}$ for $60 \mathrm{~min}$ before being washed in distilled water and mounted on slides for observation in LM with phase contrast optics. Trichocysts were made visible using DAPI fluorochrome (Sigma-Aldrich) (Coleman 1983). Volumes from cultures with a high cell abundance were fixed with $1 \%$ formaldehyde solution and stained with 10 $\mu \mathrm{g} \mathrm{ml}^{-1}$ final concentration DAPI fluorochome for $5 \mathrm{~min}$ in the dark before being examined in LM.

\section{Transmission electron microscopy (TEM)}

Two different methods were used to prepare samples for TEM observation. First, Seoane et al. (2009c) proposed a method for examining all sorts of scales covering prasinophyceans by fixing cells overnight with one drop of $1 \% \mathrm{OsO}_{4}$ (Sigma-Aldrich) and staining with uranyl acetate. In the second method, instead of using the fixative agent
$\mathrm{OsO}_{4}$, Marin and Melkonian (1994) employed glutaraldehyde and less shadowing time with uranyl acetate; shadowing and washing were done more carefully to prevent cell loss. The second method was used for the observation of flagellar hairs. In both cases, photomicrographs were taken using either a Philips CM120 or a Philips $208 \mathrm{~S}$ microscope (Koninklijke Philips Electronics N.V., Amsterdam, The Netherlands), both equipped with an Olympus SIS Morada camera (Olympus Corporation, Tokyo, Japan).

\section{Pigment analysis}

Cells of all strains analyzed were harvested in exponential growth phase for pigment extraction. Subcultures of all the strains were acclimatized to standardized experimental growth conditions, consisting of inoculating $100 \mu \mathrm{l}$ of each culture in 10-ml culture medium at a salinity of 30 in borosilicate tubes. Subcultures were incubated at $18 \pm 1^{\circ} \mathrm{C}$ under cool-white fluorescent lamps with an irradiance of $100 \mu \mathrm{mol}$ photons $\mathrm{m}^{-2} \mathrm{~s}^{-1}$ and a 12:12 $\mathrm{h}$ light:dark photoperiod. Afterwards, the exponential growth phase duration, which extended for at least five days for all strains, was determined by following the growth curves based on measured in vivo chlorophyll $a$ fluorescence of the cultures. Fluorescence was measured directly in the culture tubes every $24 \mathrm{~h}$ with a Turner Designs 10-100R fluorometer (Granéli and Moreira 1990).

A volume of $10 \mathrm{ml}$ from each strain and $20 \mathrm{ml}$ for the strain CGA09 were collected during the exponential growth phase of unialgal non-axenic cultures, filtered onto 25-mm Whatman GF/F glass fibre filters (Whatman International Ltd, Maidstone, UK), and immediately frozen in liquid nitrogen until further pigment extraction. Frozen filters were extracted under low light by grinding them with a stainless steel spatula in PTFE-lined screw capped tubes (Pyrex, Tewksbury, MA, USA) with $5 \mathrm{ml} 90 \%$ acetone HPLC grade (Panreac, Barcelona, Spain). The tubes were sonicated for $5 \mathrm{~min}$ in an ultrasonic bath (filled with a water-ice mixture). Extracts were then filtered through 0.2- $\mu \mathrm{m}, 13-\mathrm{mm}$ diameter PTFE syringe filters (Membrane Solutions, North Bend, OH, USA) to remove cell and filter debris.

The chromatography equipment employed to analyze the extracted pigments, running with Millenium32 software, was an Alliance HPLC System consisting of a 2695 separations module, a 996 diode-array detector $(1.2 \mathrm{~nm}$ optical resolution), and a 474 fluorescence detector, all by Waters (Milford, MA, USA).

Two methods were used for pigment analysis that are thoroughly described in Zapata et al. (2000) and Garrido 
et al. (2009). Both have different mobile phases (referred to as A and B solvents) but share the same column (Waters Symmetry C8, $150 \times 4.6 \mathrm{~mm}, 3.5 \mu \mathrm{m}$ particle size, $100 \AA$ pore size), solvent mixture gradient profile (time, \% B solvent: $0 \mathrm{~min}, 0 \%$; $22 \mathrm{~min}, 40 \%$; $28 \mathrm{~min}, 95 \%$; $38 \mathrm{~min}$, $95 \%$; $42 \mathrm{~min}, 0 \%)$, temperature $\left(25^{\circ} \mathrm{C}\right)$, and flow rate $(1 \mathrm{ml}$ $\left.\mathrm{min}^{-1}\right)$. With both methods, extracted pigments are separated based on their different polarites after being injected into the flow of the gradually changing solvent mixture as this elutes through the chromatographic column. To avoid distortion of early eluting pigment peaks (Zapata and Garrido 1991) and at the same time prevent losses of nonpolar pigments (Latasa et al. 2001), the injection consisted of $60 \mu \mathrm{l}$ of water, $140 \mu \mathrm{l}$ of acetone extract, and $30 \mu \mathrm{l}$ of water sequentially placed together in the automatic injector loop.

Pigments were identified by diode-array spectroscopy and by co-chromatography with standards obtained from reference cultures. The external standards for HPLC calibration were acetonic solutions of pigments isolated from mass cultures of Tetraselmis suecica (Kylin) Butcher, Micromonas pusilla (Butcher) I. Manton et M. Parke and Codium fragile (Suringar) Hariot fronds (Garrido et al. 2009), which had been quantified by Vis-spectroscopy using recommended extinction coefficients (Egeland et al. 2011).

\section{Phylogenetic analysis}

Prior to phylogenetic analysis, clonal subcultures of nonclonal strains were established by micropipetting as previously done for establishing unialgal cultures. For molecular analyses, $10 \mathrm{ml}$ of culture was centrifuged, and genomic DNA was extracted from the cell pellet using the DNeasy ${ }^{\circledR}$ Plant Mini DNA extraction Kit (Qiagen, Hilden, Germany), according to the manufacturer's instructions. PCR amplification of the small subunit (SSU) region was performed with BioMix ${ }^{\mathrm{TM}}$ (Bioline, London, UK) following the manufacturer's instructions and using the SR1-SR12 primers (Nakayama et al. 1996). Amplification products were purified using the MultiScreen HTS PCR 96-well filtration system (Millipore) and quantified with the Nanodrop spectrophotometer. Sequencing was carried out with ABI PRISM ${ }^{\mathrm{TM}}$ BIGDYE v3.1 ${ }^{\circledR}$ Terminator Sequencing Reaction ${ }^{\circledR}$ (Applied Biosystems) and an ABI PRISM 3130xl Genetic Analyzer automatic sequencer. The sequences were then edited using BioEdit v7.0.9 software (Hall 1999).

All sequences were aligned using the L-INS-I strategy implemented in MAFFT 6.833 (Katoh and Toh 2008).
Based on this alignment, three phylogenetic approaches were used: a neighbor-joining (NJ) analysis carried out with MEGA 5 (Tamura et al. 2011), with 1000 bootstraps and Kimura-2-parameters model; a maximum likelihood (ML) analysis carried out with RAxML (Stamatakis 2006), with GTR $+\mathrm{G}+\mathrm{I}$ model and 1000 bootstrap samples; and a Bayesian (B) analysis carried out with MrBayes 3.2 (Ronquist and Huelsenbeck 2003), using "lset nst=6 rates=invgamma", $10^{6}$ generations and discarding the first $25 \%$ of the trees.

The $18 \mathrm{~S}$ sequence dataset used for the phylogenetic analyses consisted of 50 sequences: 13 from this study and 37 from the GenBank data base (https://www.ncbi.nlm. nih.gov/genbank/).

\section{Results}

\section{Pyramimonas orientalis Butcher ex McFadden, Hill et Wetherbee 1986 (Figures 1-12)}

\section{Synonym}

Pyramimonas plurioculata Butcher.

\section{Morphology}

Cells with a wide variety of forms were recorded, from near oval with the anterior end somewhat truncated to pyramidal and more or less oblong (Figures 1 and 2). Cells were 5-12 $\mu \mathrm{m}$ long and 4-9 $\mu \mathrm{m}$ wide, while the four flagella ranged from 5 to $14 \mu \mathrm{m}$ in length. In both apical or anterior view, cells appeared almost square, while in antapical or posterior view they looked rounded, and sometimes dorsoventrally flattened (Figures 3-5). The chloroplast was yellowish-green with one of its sinuses larger than the others and showing one, two (most frequently), or even three pigmented bodies that could be identified as eyespots (Figures 1-3 and 5, 6); as discussed below, some of them could be the red globules described before for this species. The pyrenoid was rounded, elliptical, or oval and usually covered by a cup-shaped starch grain (Figure 7, arrowhead) or by two cupulate starch grains (Figure 8). Cells in division, but not only those cells, usually possessed a posterior tail (Figure 9). Division was by mitosis in which, sometimes, daughter cells underwent further division before cytokinesis, giving rise to a multilobed form (not shown). Box scales were 

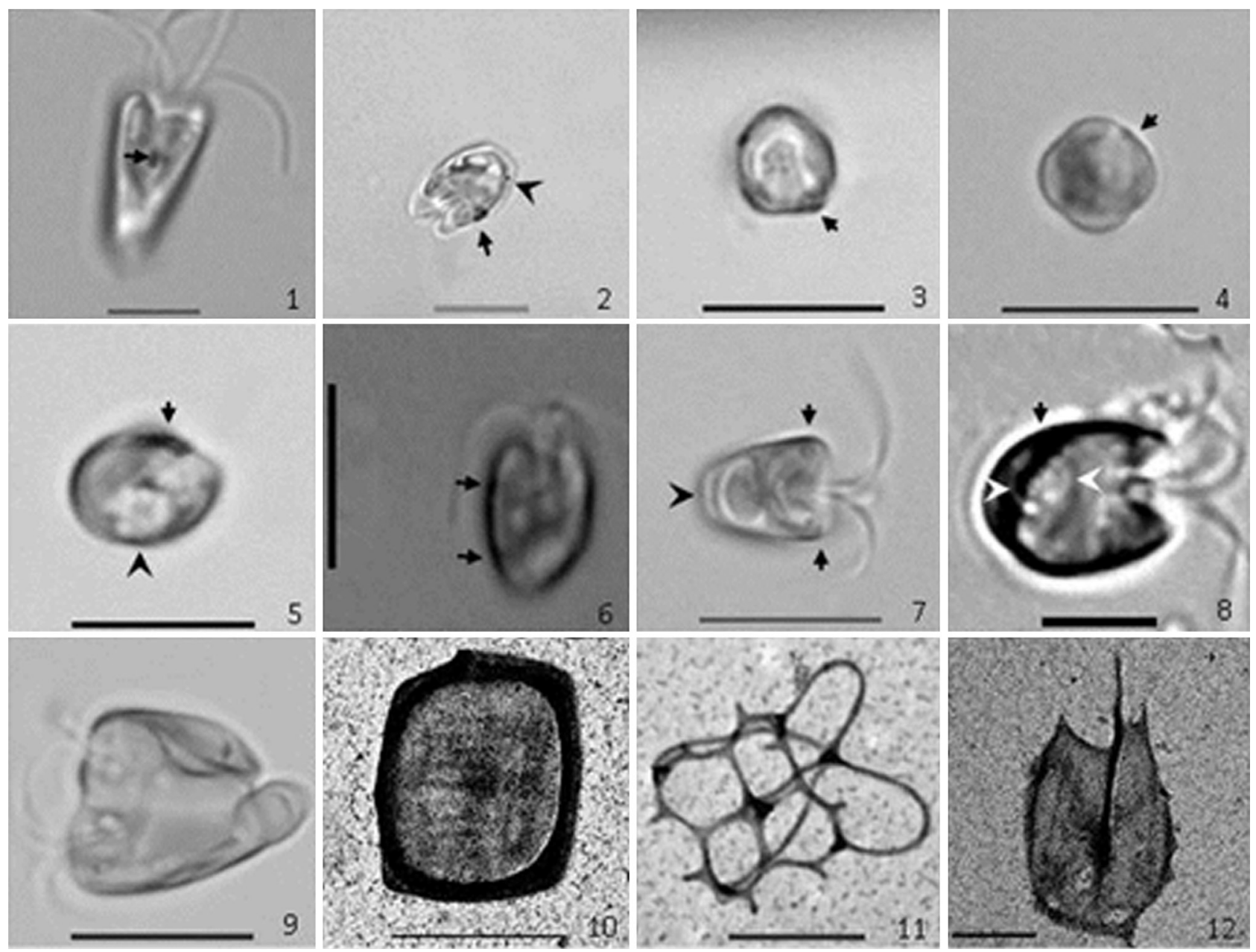

Figures 1-12 Cells and scales of Pyramimonas orientalis from the Nervión River estuary, LM (1-9), TEM (10-12).

(1) Cell with two adjacent eyespots (arrow), strain CGA13. (2) Cell with two eyespots in its central part (arrow) and another pigmented body, which may be a red globule due to its position in the posterior end of the cell (arrowhead), CGA13. (3) Cell in apical view with a rounded profile and 2 eyespots (arrow), CGA09. (4) Cell in apical view with a square profile showing one chloroplast sinus (arrow) larger than the others, CGA12. (5) Antapical view of a dorsoventrally flattened cell showing the parietal position of the pyrenoid (arrowhead) and one eyespot (arrow), CGA09. (6) Cell with two pigmented bodies (arrows), CGA14. (7) Cell showing a pyrenoid with a large starch grain (arrowhead) and two other grains (arrows) in its anterior end, CGA14. (8) Cell with a pyrenoid (arrow) covered by two starch grains (arrowheads), CGA13. (9) Cell in division showing the posterior tail of daughter cells, CGA12. (10) Box scale showing fine striation on its base plate, CGA13. (11) Crown scale, CGA14. (12) Limuloid scale in distal view, CGA13. Scale bars: $10 \mu \mathrm{m}$ (Figures 2-7 and 9), $5 \mu \mathrm{m}$ (Figures 1, 5, and 8), $200 \mathrm{~nm}$ (Figures 10 and 11), $100 \mathrm{~nm}$ (Figure 12).

usually square or occasionally rectangular, with some showing striation patterns at their base which were not distinguished well by the shadowing techniques used in this study (Figure 10, Table 2). Crown scales showed a quadrangular, slightly four-lobed base bearing eight spines (Figure 11, Table 2). Limuloid scales had two auxiliary spines and four ridges from the central spine to the edge of the scale (Figure 12, Table 2), showing three perforations at the posterior end, two near the edge, and one next to the central spine, and except in strain CGA14, they showed one or two parallel striations on each side of the central spine. T-hairs from the flagella showed a proximal filament, a tubular shaft consisting of proximal and distal regions, and two distal subunits of spherical to discoid form; no distal filament was observed (Table 2).

\section{Distribution}

McFadden et al. (1986) recorded the presence of Pyramimonas orientalis in Australian waters and cited previous occurrences in New Zealand, Egypt, Israel, the Mediterranean Sea, Norway, Denmark, Finland, UK, Greenland, the Arctic, and the west coast of Canada and USA. 
Table 2 Scale types with size range and main characteristics for 11 strains of prasinophytes isolated from the Nervión River estuary and nearby sampling sites.

\begin{tabular}{|c|c|c|c|c|}
\hline Species & Strain & Scale type & Scale size $(\mathrm{nm})$ & Special features \\
\hline \multirow[t]{5}{*}{ Pyramimonas orientalis } & \multirow[t]{5}{*}{ CGA09, 12-14 } & Box $^{a}$ & $234-332(S)$ & Striation in base \\
\hline & & & $254-386 \times 201-287(R)$ & \\
\hline & & Crown $^{b}$ & $199-305$ & 4-lobed base with 8 spines \\
\hline & & Limuloid $^{c}$ & $254-400 \times 156-220$ & $2 \mathrm{AS}, 4 \mathrm{Rd}, 3 \mathrm{P}$ and $1-2 \mathrm{PS}$ \\
\hline & & T-hair ${ }^{d}$ & $895-923^{e}$ & $\begin{array}{l}\operatorname{PF}\left(102-135^{\mathrm{e}}\right), \operatorname{PRS}(146-183 \times 14-18), \text { DRS } \\
\left(577-595^{\mathrm{e}} \times 14-18\right) \text { and } 2 \text { DS }\left(11-17^{\mathrm{e}}\right)\end{array}$ \\
\hline \multirow[t]{4}{*}{ Pyramimonas moestrupii } & \multirow[t]{4}{*}{ CGA10 } & Box $^{a}$ & $313-378$ & Walled up, hollow central boss and many $P$ \\
\hline & & Crown $^{b}$ & $283-318^{\mathrm{e}} \times 338^{\mathrm{e}}$ & Curved uprights with $2-3$ spines \\
\hline & & Limuloid $^{c}$ & $293-354 \times 179-208$ & $2 \mathrm{AS}, 4 \mathrm{Rd}, 1+\mathrm{P}, 1$ bigger and $1-2 \mathrm{PS}$ \\
\hline & & T-hair ${ }^{d}$ & $727-1024$ & $\begin{array}{l}\operatorname{PF}(50-122), \operatorname{PRS}(440-524 \times 17-29) \\
\text { DRS }(357-418 \times 12-20) \text { and DF }\left(163^{\mathrm{e}}\right)\end{array}$ \\
\hline \multirow[t]{5}{*}{ Pyramimonas grossii } & \multirow[t]{5}{*}{ CGA11 } & Boxa & $237-298(S)$ & $20-32 \mathrm{P}$ forming a rosette \\
\hline & & & $267-294^{\mathrm{e}} \times 235-258^{\mathrm{e}}(\mathrm{R})$ & \\
\hline & & Crown $^{\mathrm{b}}$ & $236-294^{\mathrm{e}} \times 224-328$ & $\begin{array}{l}\text { Curved uprights with } 2 \text { spines, distal ones } \\
\text { larger and forming a swastika }\end{array}$ \\
\hline & & Limuloid ${ }^{c}$ & $243-432 \times 147-180$ & $\begin{array}{l}2 \mathrm{AS}, 4 \mathrm{Rd}, 2 \text { big and sometimes more } \\
\text { smaller P, } 1 \text { like an inverted comma }\end{array}$ \\
\hline & & T-hair ${ }^{d}$ & $1065-1196^{\mathrm{e}}$ & $\begin{array}{l}\operatorname{PF}\left(110-139^{\mathrm{e}}\right), \operatorname{PRS}(731-837 \times 15-24), \mathrm{DRS} \\
\left(138-255^{\mathrm{e}} \times 10-16^{\mathrm{e}}\right), 2 \mathrm{DS}\left(12-13^{\mathrm{e}} \times 16-18^{\mathrm{e}}\right) \\
\text { and DF }\left(138-210^{\mathrm{e}}\right)\end{array}$ \\
\hline \multirow[t]{4}{*}{ Pyramimonas robusta } & \multirow[t]{4}{*}{ CGA15 } & Box ${ }^{a}$ & $269-360(S)$ & 4 (8) spines in the side wall, lobed \\
\hline & & & $312-317 \times 269-282^{\mathrm{e}}(\mathrm{R})$ & appearance of aperture \\
\hline & & Crown $^{\mathrm{b}}$ & $327-369^{\mathrm{e}} \times 267-392^{\mathrm{e}}$ & $\begin{array}{l}\text { Outer framework raised where it meets the } \\
\text { curved uprights }\end{array}$ \\
\hline & & Limuloid ${ }^{c}$ & $332-447 \times 177-284$ & $3 \mathrm{AS}, 5 \mathrm{Rd}$, various $\mathrm{P}, 1$ near the central spine \\
\hline \multirow[t]{4}{*}{ Pyramimonas propulsa } & \multirow[t]{4}{*}{ CGA16 } & Box $^{a}$ & $219-249^{e}(\mathrm{~S})$ n.d. (R) & $\begin{array}{l}\text { Uprights instead side walls and a spine- } \\
\text { bearing framework }\end{array}$ \\
\hline & & Crown $^{b}$ & $283-337^{\mathrm{e}}(\mathrm{S})$ & A spine-bearing framework, and a windowed, \\
\hline & & & $341-358^{\mathrm{e}} \times 255-292^{\mathrm{e}}(\mathrm{R})$ & cupulate structure with a central boss \\
\hline & & Limuloid $^{c}$ & $325-416^{\mathrm{e}} \times 187-220^{\mathrm{e}}$ & 3 AS and a cobweb structure with 6 radial ribs \\
\hline \multirow[t]{3}{*}{ Mamiella gilva } & \multirow[t]{3}{*}{ CGA06 } & Small body & $185-207^{e} \times 135-153^{e}$ & $\begin{array}{l}\text { Octagonal, cobweb structure resembling a } \\
\text { rectangle with flattened corners }\end{array}$ \\
\hline & & Large body & $242-286^{e}$ & $\begin{array}{l}\text { More or less square or octagonal, cobweb } \\
\text { structure }\end{array}$ \\
\hline & & Flagellarc & $330-383^{\mathrm{e}} \times 237-262^{\mathrm{e}}$ & $\begin{array}{l}\text { Similar to small body scales or hexagonal, } \\
\text { but with adnate spine }\end{array}$ \\
\hline \multirow[t]{3}{*}{ Nephroselmis pyriformis } & \multirow[t]{3}{*}{ CGA07-08 } & Small stellate ${ }^{f}$ & $\begin{array}{r}44-45^{\mathrm{e}} \times 41-55^{\mathrm{e}}(\mathrm{CGA} 07) \\
\text { and } 37-50(\mathrm{CGA} 08)\end{array}$ & $\begin{array}{l}\text { Bipolar (8: } 1+1: 2 / 3, \text { CGA07) or unipolar } \\
(9: 1: 2 / 4, \text { CGA08) }\end{array}$ \\
\hline & & T-hair ${ }^{d}$ & $384-466$ & 8-11 DS (CGA07) or 14-15 DS (CGA08) \\
\hline & & Tip hair & n.d. & $\begin{array}{l}\text { DRS fragmented in } 7 \text { (CGA08) or } 8 \text { (CGA07) } \\
\text { segments of different length }\end{array}$ \\
\hline
\end{tabular}

Notes: Scale type: anly width indicated, except for length and width for rectangular scales; ${ }^{\mathrm{D}}$ Only width or height and width indicated,

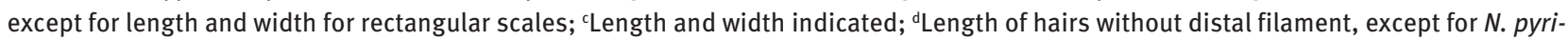
formis where the proximal filament was not taken into account, segment length is shown between brackets in special features column, except diameter or length and width for distal subunits; ${ }^{\mathrm{e}}$ Range of size based on <10 records; ${ }^{\mathrm{f}} \mathrm{Height}$ and diameter for scale of CGA07 and diameter only for CGA08, scale formula as per Bell (2008). Scale size: S, square scale; R, rectangular scale. n.d., no data. Special features: AS, auxiliary spine; DF, distal filament; DRS, distal region of shaft; DS, distal subunit; P, perforation; PF, proximal filament; PRS, proximal region of shaft; PS, parallel striation; Rd, ridge.

Furthermore, Pienaar and Sym (2002) reported this species in Africa between Namibia and Mozambique, Throndsen et al. (2007) in Norway, Smith and Hobson (1994) and Bérard-Therriault et al. (1999) in Canada, Bergesch et al.
(2008) in Brazil, and Hallegraeff et al. (2010) in Australia. It is the first time this species is reported from the Iberian Peninsula. Therefore, $P$. orientalis can be regarded as a cosmopolitan species. 


\section{Pyramimonas moestrupii McFadden 1986 (Figures 13-21)}

\section{Synonym}

Pyramimonas norrisii Sym et Pienaar.

\section{Morphology}

Cells were 6-11 $\mu \mathrm{m}$ long and 4-6 $\mu \mathrm{m}$ wide, with four flagella ranging from 6 to $11 \mu \mathrm{m}$ in length. The anterior end was truncated or slightly rounded and the posterior elliptical to conical (Figures 13 and 14). In apical view, the cells were rounded or almost square in profile, while rounded in antapical view. The chloroplast was yellowish-green, with one or two eyespots of an intermediate color between yellow and red (Figures 13-17). The pyrenoid, which was not visible in all cells, showed a sheath consisting of a cupshaped starch grain (Figures 14 and 16). There were occasionally some granules associated with the chloroplast lobes (Figure 16). Multilobed forms, as described above for Pyramimonas orientalis, were also observed in this species (Figure 17). Box scales showed a hollow central boss with a walled up interior and a base with a large number of perforations on it (Figure 18, Table 2). Crown scales possessed a structure similar to the one described for $P$. orientalis, with the exception that each of the curved uprights had two or three spines that may be oriented in different planes (Figure 19, Table 2). Limuloid scales were very similar to those of $P$. orientalis, with two auxiliary spines and four ridges rising from the central spine (Figure 20, Table 2). However, only a single striation on each side of the central spine was observed, extending parallel to the spine and, when more than one posterior perforation was observed, one was bigger than the others. T-hairs showed a proximal filament with little contrast at its proximal end, a shaft divided into a clearly channelled, slightly larger and thicker proximal region, and a distal region, and finally, crowning the hair, what seemed to be a distal filament was observed on a single specimen (Figure 21, Table 2).

\section{Distribution}

Pyramimonas moestrupii has been previously recorded from the coasts of Australia, New Zealand, and Southern Africa between Namibia and Mozambique (McFadden et al. 1986, Sym and Pienaar 1991, 1995, Hallegraeff et al. 2010), as well as in Nivá Bay, Denmark (Danish Biodiversity Information Facility, DanBIF, http://danbif.dk/ english). This species is for the first time recorded in the Gulf of Biscay and the Iberian Peninsula.

\section{Pyramimonas grossii Parke 1949 (Figures 22-37)}

\section{Morphology}

Cells were 6-10 $\mu \mathrm{m}$ long and 5-8 $\mu \mathrm{m}$ wide, with four flagella ranging from 5 to $8 \mu \mathrm{m}$ in length. Cell shape varied from rounded to oval, ellipsoid or pyramidal, but with the anterior end truncated and, sometimes, with small notches noticeable corresponding to the anterior lobes of the cell (Figures 22-24). Cells were rounded or slightly quadrilobate in apical view (Figures 25 and 26). The chloroplast was yellowish-green with a single orange eyespot (Figures 24-26). The sheath of the single pyrenoid was formed by two dome-shaped grains (Figure 24). Up to eight granules (two per chloroplast lobe) were observed in the cytoplasm surrounding the flagellar pit, presumably trichocysts (Figures 23 and 26-29), at least some fluoresced in DAPI-stained cells (Figures 28 and 29). The presence of these organelles was confirmed in TEM (Figure 30). Box scales were square or rectangular, with the base perforated by 20-32 pores forming a characteristic rosette (Figure 31, Table 2). Crown scales showed a basal framework similar to the one of Pyramimonas orientalis, but in Pyramimonas grossii, each of the curved uprights had two spines, the distal spines larger and usually rising above the linkage zone of the uprights to form a swastika appreciable in the distal view of the scale (Figure 32, Table 2), while the basal cross of the framework was lacking and the central strut was suspended (Figure 33). Limuloid scales had two auxiliary spines and four ridges (Figure 34, Table 2). They showed two larger perforations at the posterior end, one of them resembling an inverted comma, and sometimes smaller ones. T-hairs were composed of a proximal filament, a shaft with two well-differentiated regions consisting of a thicker proximal region and a thinner, more electron-lucent distal region that ended in a terminal thickening, two more or less discoid distal subunits, and a distal filament (Figures 35-37, Table 2).

\section{Distribution}

Pyramimonas grossii can be regarded as a cosmopolitan species. It has been reported in the UK (Parke 1949, Butcher 1959, Manton et al. 1963, Pennick and Clarke 1976), New Zealand (Norris 1964), Norway, the Mediterranean Sea, Denmark, Japan, the Arctic Ocean, Southern African coast (McFadden et al. 1986, Sym and Pienaar 1993, Pienaar and Sym 2002, Throndsen et al. 2007), Brazil (Bergesch et al. 2008), Australia and Tasmanian waters (LeRoi and 


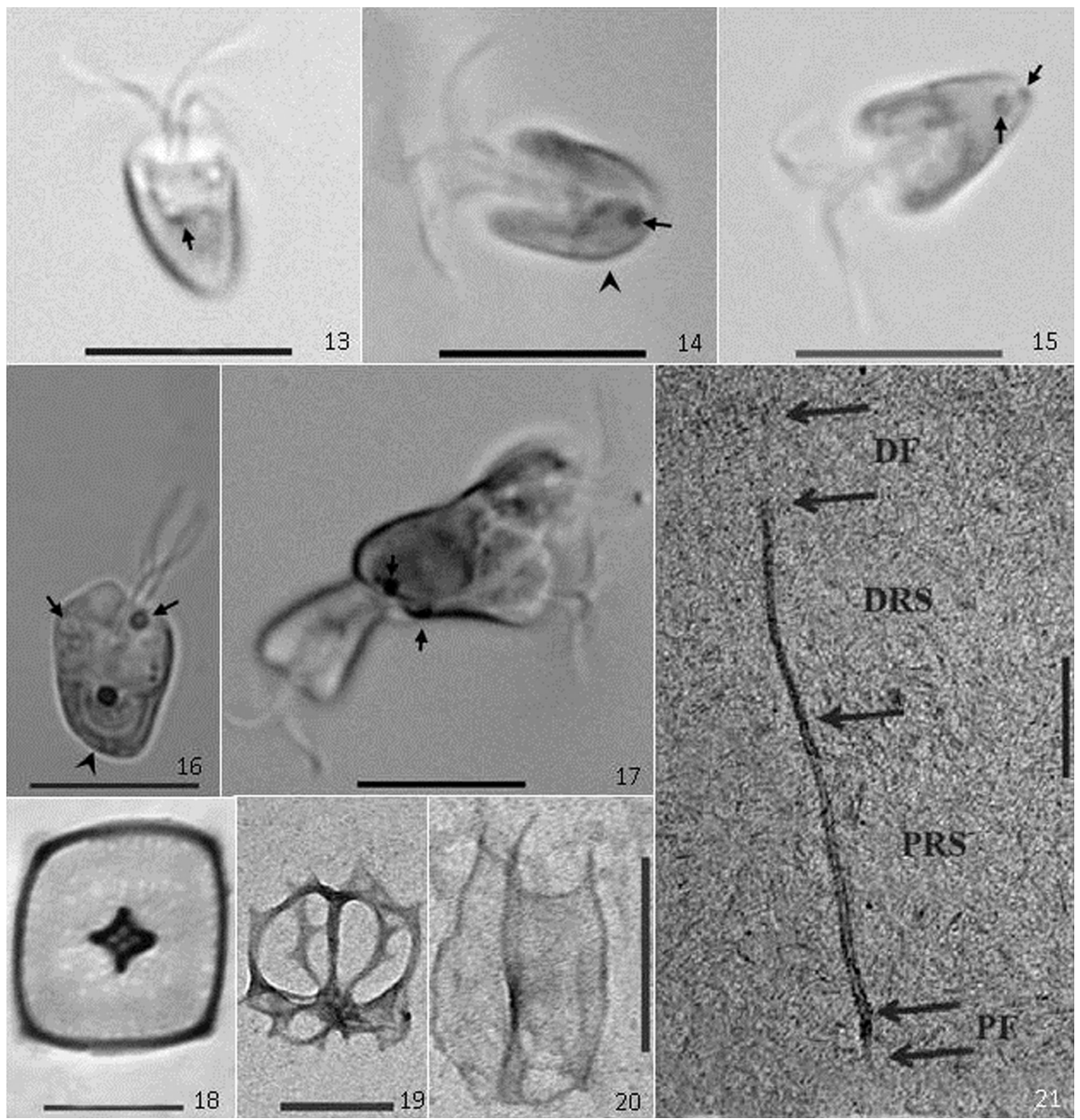

Figures 13-21 Cells and scales of Pyramimonas moestrupii, strain CGA10, from the Nervión River estuary, LM (13-17), TEM (18-21). (13) Cell with truncated anterior and conical posterior ends showing the eyespot (arrow) in its mid part. (14) Cell showing a chloroplast sinus reaching its posterior rounded end where a pyrenoid (arrowhead) and a pigmented body (arrow) are noticed. (15) Cell with two pigmented bodies (arrows) in its posterior end. (16) Cell showing a pyrenoid (arrowhead) with a clearly noticeable pigmented body overlapping its anterior part and granules associated with the chloroplast lobes (arrows). (17) Multilobed form showing pigmented bodies (arrows). (18) Box scale in distal view showing the central hollow boss and the perforation pattern of the base plate. (19) Lateral view of a crown scale. (20) Limuloid scale. (21) T-hair delimiting regions (arrows) formed by the distal filament (DF), the distal region of the shaft (DRS), the proximal filament (PF) and the proximal region of the shaft (PRS). Scale bars: $10 \mu \mathrm{m}$ (Figures 13-17), $200 \mathrm{~nm}$ (Figures 18-21). 


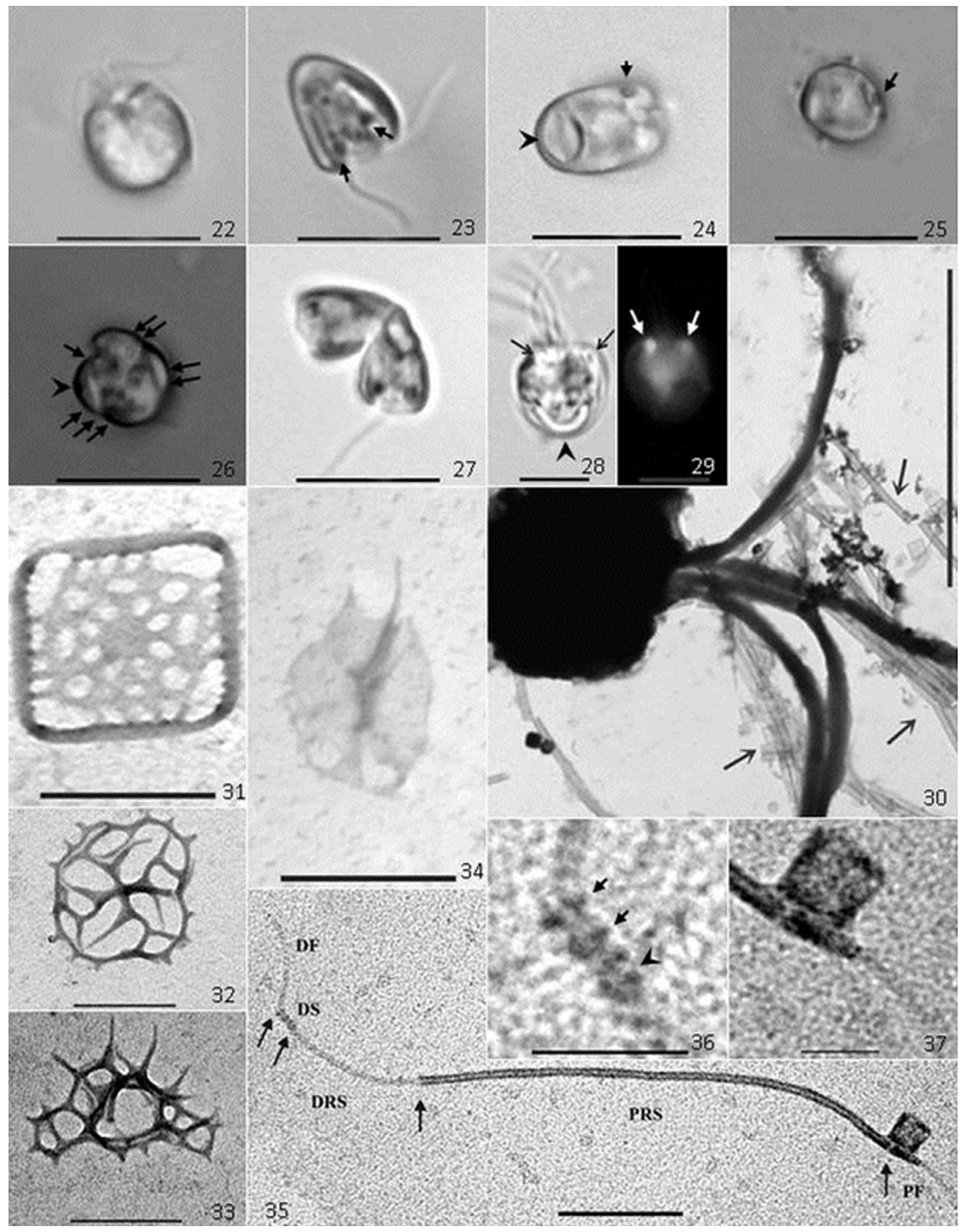

Figures 22-37 Cells and scales of Pyramimonas grossii, strain CGA11, from the Nervión River estuary, LM (22-29), TEM (30-37).

(22) More or less rounded cell. (23) Pyramidal cell with anterior lobes of the cytoplasm and two grains (arrows), presumably trichocysts. (24) Almost elliptical cell showing the eyespot (arrow) and bipartite elliptical pyrenoid covered by two starch grains (arrowhead). (25) Cell with a rounded profile showing the exterior location of the eyespot (arrow) in a chloroplast lobe. (26) Quadrilobate cell in polar view showing up to eight possible trichocysts (arrows) and the eyespot (arrowhead). (27) Dividing cell. (28) Glutaraldehyde-fixed and DAPI-stained cell showing anterior grains (arrows) and a single starch grain covering the pyrenoid (arrowhead). (29) Previous cell in epifluorescence showing DAPIstained trichocysts (arrows). (30) Cell with projected ejectosomes (arrows). (31) Box scale. (32) Crown scale. (33) Crown scale in lateral view. (34) Limuloid scale. (35) T-hair-delimiting regions (arrows) formed by the distal filament (DF), the distal subunit(s) (DS), the distal region of the shaft (DRS), the proximal region of the shaft (PRS), and the proximal filament (PF). (36) Detail of distal subunits (arrows) and terminal thickening of the distal region (arrowhead) of the shaft of T-hair. (37) Detail of the proximal filament of T-hair. Scale bars: $10 \mu \mathrm{m}$ (Figures 22-27), $5 \mu \mathrm{m}$ (Figures 28-30), $200 \mathrm{~nm}$ (Figures 31-35), $50 \mathrm{~nm}$ (Figures 36 and 37). 
Hallegraeff 2006, Hallegraeff et al. 2010), USA (Thomsen and Buck 1998), and Canada (Smith and Hobson 1994).

\section{Pyramimonas robusta Pienaar et Sym 1997 (Figures 38-49)}

\section{Morphology}

Cells were 6-12 $\mu \mathrm{m}$ long and 5-10 $\mu \mathrm{m}$ wide, with four flagella ranging from 10 to $18 \mu \mathrm{m}$ in length. Cells were oblong in shape, varying from elliptical to obovate (Figure 38). In apical view, their profile was rounded, square, or with a dorsoventral compression that sometimes gives the apical part of the cells at least a rhomboid shape (Figures 39-41), while in antapical view, cells were rounded (Figure 42). The chloroplast was yellowish-green, and the eyespot yellow and located on one side of one of the lobes (Figures 38, 40, 42, and 43). The pyrenoid had a sheath composed of two large grains (Figures 42 and 44). Rows of puncta were present parallel to each of the chloroplast lobes, extending from the anterior to the posterior part of the cell where they converged (Figure 44). No multilobed forms were observed during cell division (Figure 45). Box scales were square or rectangular, and their base plates did not appear to be perforated (Figures 46 and 47, Table 2),
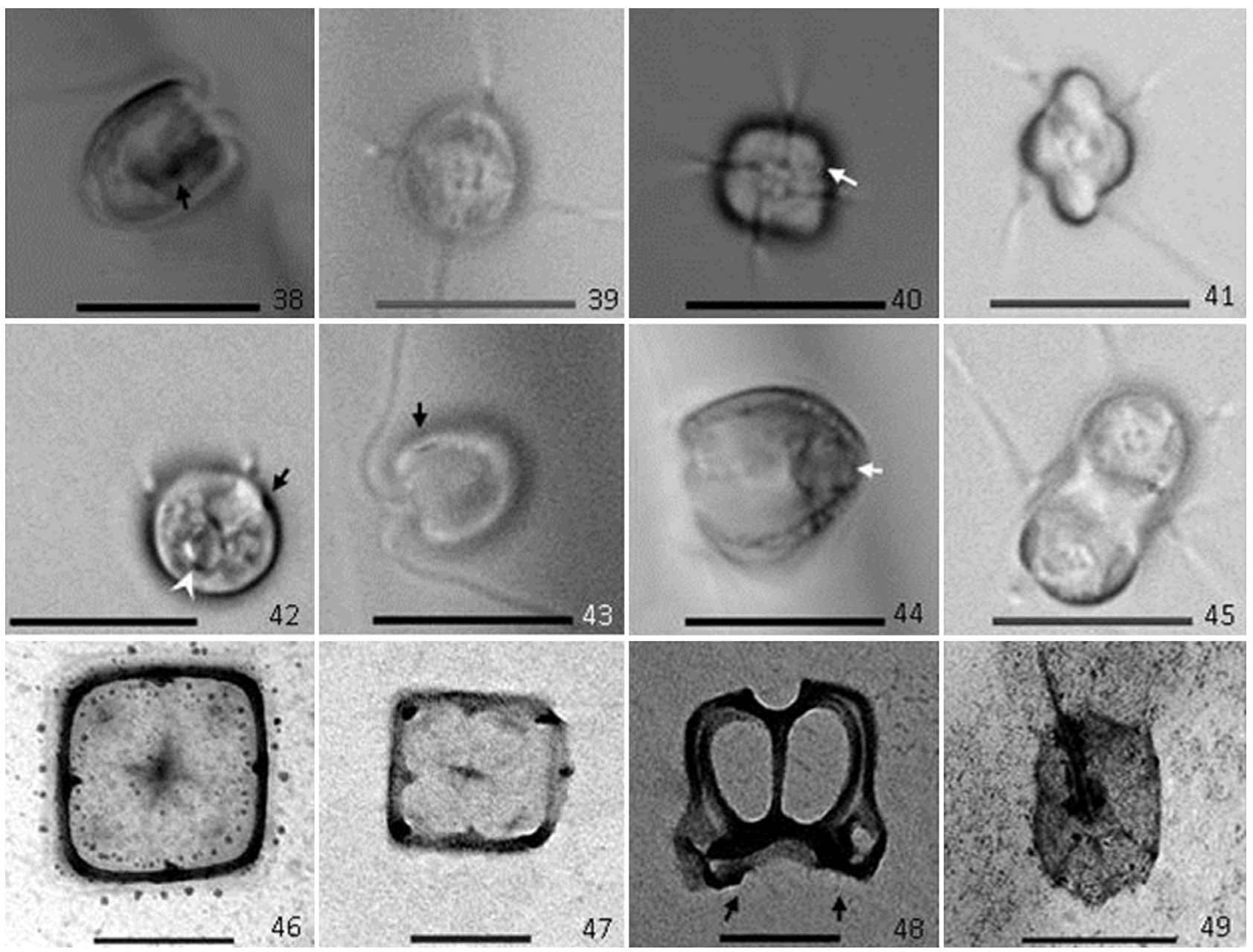

Figures 38-49 Cells and scales of Pyramimonas robusta, strain CGA15, from the Nervión River estuary, LM (38-45), TEM (46-49).

(38) Cell showing the eyespot in its mid part (arrow) and the flagellar pit. (39) Cell with a rounded profile in apical view. (40) Cell with a quadrangular profile in apical view showing an eyespot (arrow). (41) Cell with a rhomboid profile in apical view showing anterior lobes of the cytoplasm. (42) Cell in antapical view showing the basal position of the pyrenoid (arrowhead) covered by two starch grains, note one of the sinuses of the chloroplast reaching the posterior end of the cell and the eyespot (arrow). (43) Cell with an eyespot located toward its anterior end (arrow). (44) Cell showing a pyrenoid (arrow) and rows of puncta extending parallel to the lateral sides of the cell. (45) Dividing cell. (46) Four-spine box scale in distal view. (47) Eight-spine box scale in distal view. (48) Crown scale in lateral view, note the small spines of the outer framework of the base (arrows). (49) Limuloid scale. Scale bars: $10 \mu \mathrm{m}$ (Figures 38-45), $200 \mathrm{~nm}$ (Figures 46-49). 
showing variation in the number of spines rising from the center of each rim of the scale. These spines, usually four in number, were mainly oriented inward on the scale, giving a lobed appearance to its aperture. However, scales with four additional spines (eight in total) on the distal margin of the scale rim, were also observed, one in each corner. Crown scales had a square base with the outer framework raised where it meets the curved uprights and bearing small spines (Figure 48, Table 2). Limuloid scales had three auxiliary spines and five ridges (Figure 49, Table 2). They also possessed perforations at the posterior end, one of them close to the end of the central spine and the rest close to the scale edge.

\section{Distribution}

Pyramimonas robusta has been previously reported only in surf zones of South African coast and Japanese waters (Inouye et al. 1985, Pienaar and Sym 1997). This record of $P$. robusta represents the first citation for the North Atlantic.

\section{Pyramimonas propulsa Moestrup et Hill 1991 (Figures 50-63)}

\section{Morphology}

Cells were 12-18 $\mu \mathrm{m}$ long and 7-12 $\mu \mathrm{m}$ wide, with eight flagella ranging from 14 to $29 \mu \mathrm{m}$ in length. Cells were campanulate to pyramidal in shape, with a truncated anterior end and a conical, elliptical, or somewhat oval and sometimes quite irregular posterior end (Figures 50-53). In apical view, the cells were octagonal, superficially lobed in the form of a four-leaf clover or rectangular in profile with rounded corners (Figures 54 and 55). In antapical view, the cells were rounded in profile, or quadrangular with rounded corners (Figure 56). The chloroplast was green with yellow and brown shades, and close to the anterior end of some cells, the four lobes of the chloroplast were bifurcated, so in apical view, cells with four or eight conspicuous lobes were observed (Figures 51, 54, 55, 57, and 58). Two opposite sinuses between the lobes were larger, reaching the antapical end of the cell and forming a cytoplasmic channel (Figure 56), with the result that some cells when viewed in longitudinal plane may show a kind of cytoplasmic island not occupied by the chloroplast in their posterior end (Figures 50 and 52). One or two more or less pill-shaped eyespots, yellow in color, can be found toward the central or posterior part of the cell (Figures 51,
52, and 57). The pyrenoid was rounded, elliptical, or irregularly shaped and located in a basal central position (Figures 51, 56, and 59). It was not noticeable in all the cells, but with azocarmine $\mathrm{G}$ staining, a sheath composed of four grains was observed (Figure 59). In some cells, a large number of small dark-shaded vesicles or grains were observed along the chloroplast lobes (Figures 52 and 53). On other occasions, a grain was observed in the anterior end of each of the chloroplast lobes (Figure 59). No multilobed forms were observed during cell division (Figure 60). Box scales were square, with uprights instead of side walls, and a spine-bearing framework (Figure 61, Table 2). One rectangular specimen of box scale was observed with somewhat larger dimensions (not shown). Crown scales were square or rectangular, also with a spine-bearing framework, and showed a windowed, cupulate structure with a central boss (Figure 62, Table 2). Limuloid scales had three auxiliary spines and a cobweb-structure with six radial ribs (Figure 63, Table 2).

\section{Distribution}

Pyramimonas propulsa, in many cases identified as Pyramimonas aff. amylifera Conrad, has been reported from Tasmania (LeRoi and Hallegraeff 2006), Australia (McFadden et al. 1986, Moestrup and Hill 1991, Hallegraeff et al. 2010), Japan (Inouye and Horiguchi 1982, Inouye et al. 1985), South Africa (Pienaar 1978, Sym and Pienaar 1997), Italy (Moestrup et al. 1987, Moestrup and Hill 1991), France (Moestrup and Hill 1991), and in the Kattegat Strait, between the Baltic and North Seas (Throndsen et al. 2007). This record may represent the first confirmed occurrence of $P$. propulsa along the Spanish coastal waters, even if it has been previously reported from the Nervión River estuary, because its identification has not been checked before with electron microscopy (Orive et al. 2004).

\section{Mamiella gilva (Parke et Rayns) Moestrup 1984 (Figures 64-76)}

\section{Synonym}

Nephroselmis gilva Parke et Rayns.

\section{Morphology}

Cells were 5-8 $\mu \mathrm{m}$ long and 4-7 $\mu \mathrm{m}$ high, with two equal, subequal, or even unequal flagella ranging from 

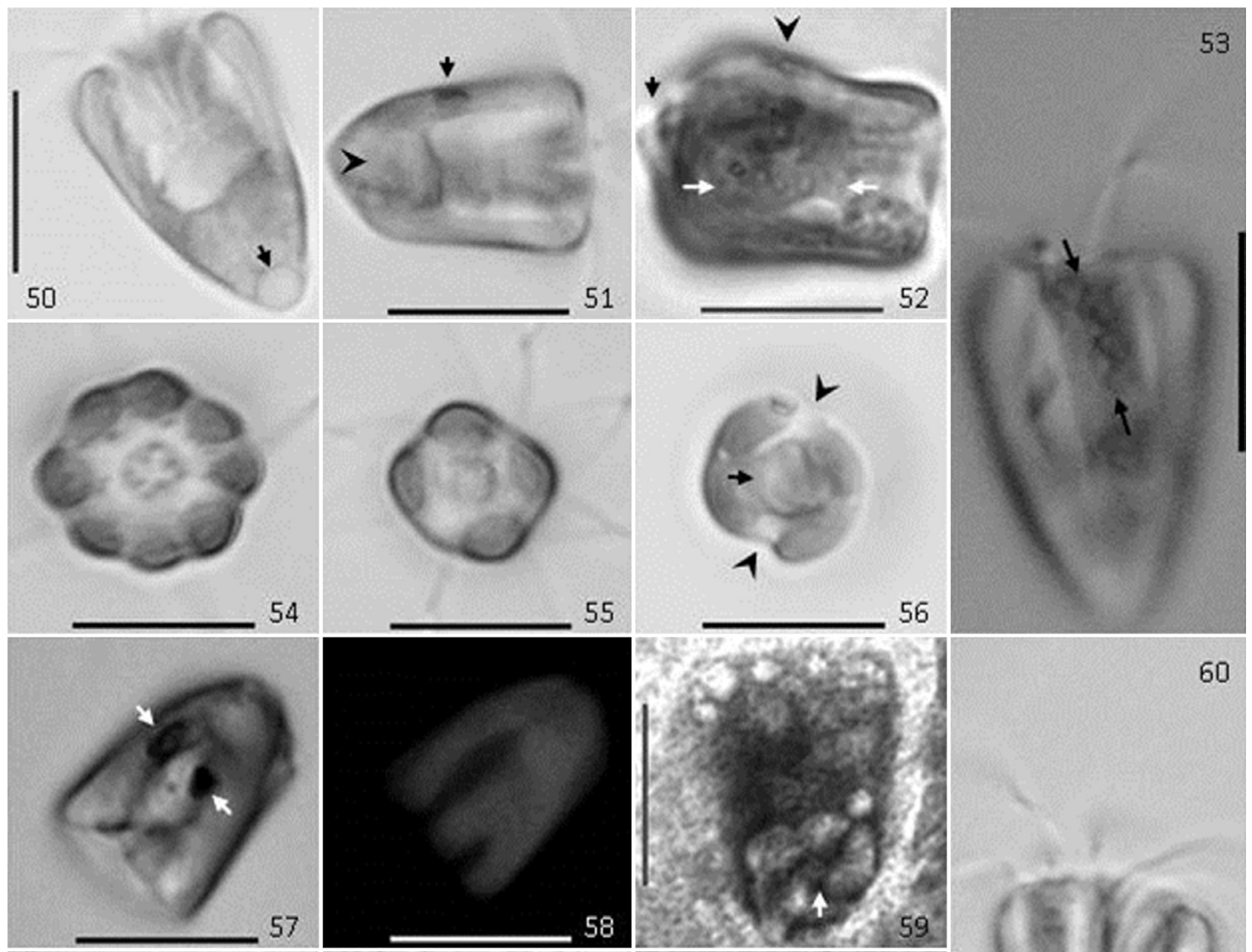

57
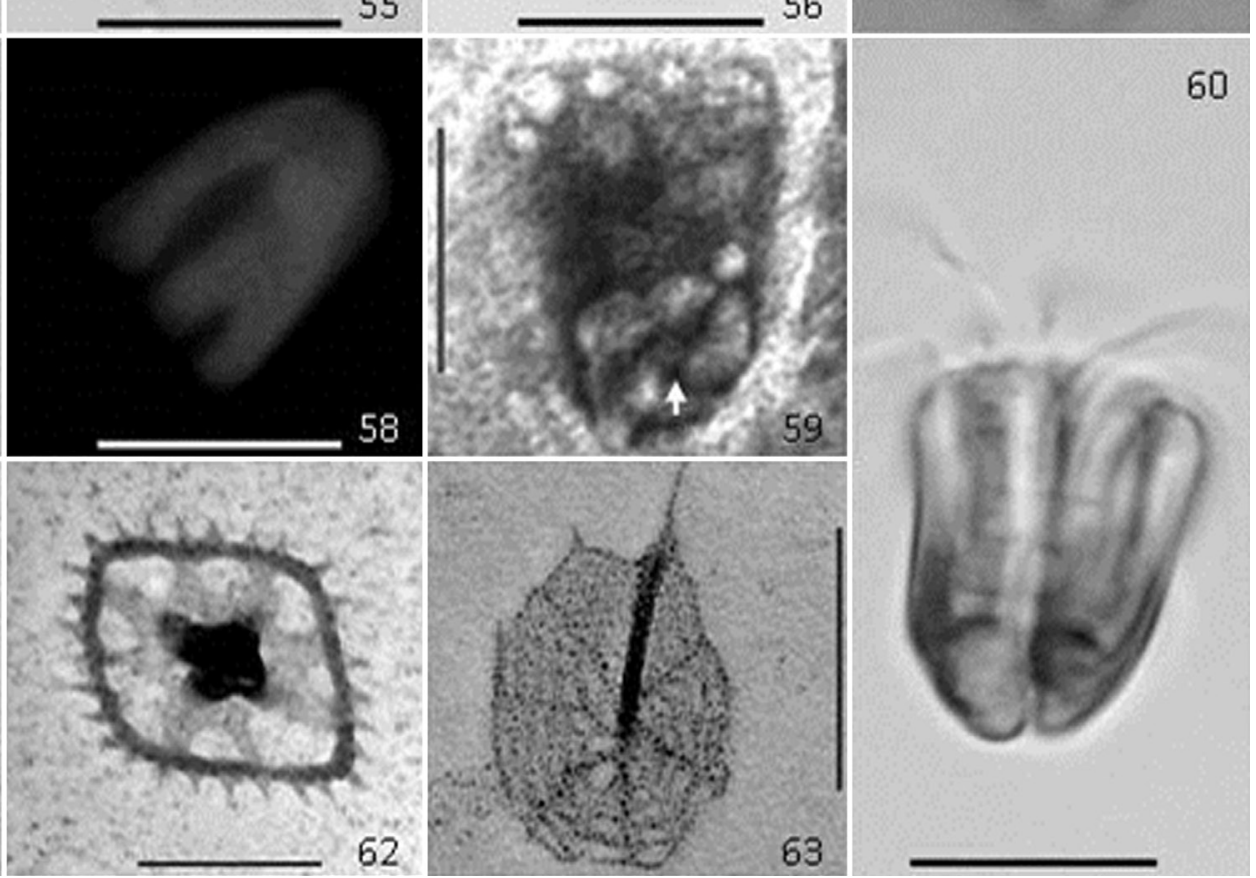

Figures 50-63 Cells and scales of Pyramimonas propulsa, strain CGA16, from the Nervión River estuary, LM (50-60), TEM (61-63).

(50) Cell showing the extension of the flagellar pit and the posterior cytoplasmic island (arrow). (51) Cell showing an eyespot (arrow), an irregularly shaped pyrenoid (arrowhead) and the anterior bifurcation of one of the chloroplast lobes. (52) Campanulate cell with a posterior cytoplasmic island (black arrow) and concave sides showing a row of possible puncta (between white arrows) and an eyespot (arrowhead). (53) Pyramidal cell with a row of possible puncta (between arrows) extending parallel to a chloroplast lobe. (54) Apical view of a cell with the anterior lobulate cytoplasm in a four-leaf clover pattern. (55) Apical view of a cell with a quadrangular profile. (56) Antapical view of a cell with a quadrangular profile showing a basal pyrenoid (arrow) and two chloroplast sinuses reaching its posterior end (arrowheads). (57) Cell with two eyespots (arrows) in adjacent lobes of the chloroplast. (58) Cell in epifluorescence showing the anterior bifurcation of one of the chloroplast lobes. (59) Azocarmine G-stained cell showing the pyrenoid (arrow) surrounded by four starch grains and five anterior grains associated with the chloroplast lobes. (60) Dividing cell. (61) Box scale in distal view. (62) Crown scale in proximal view. (63) Limuloid scale. Scale bars: $10 \mu \mathrm{m}$ (Figures 50-60), $200 \mathrm{~nm}$ (Figures 61-63). 

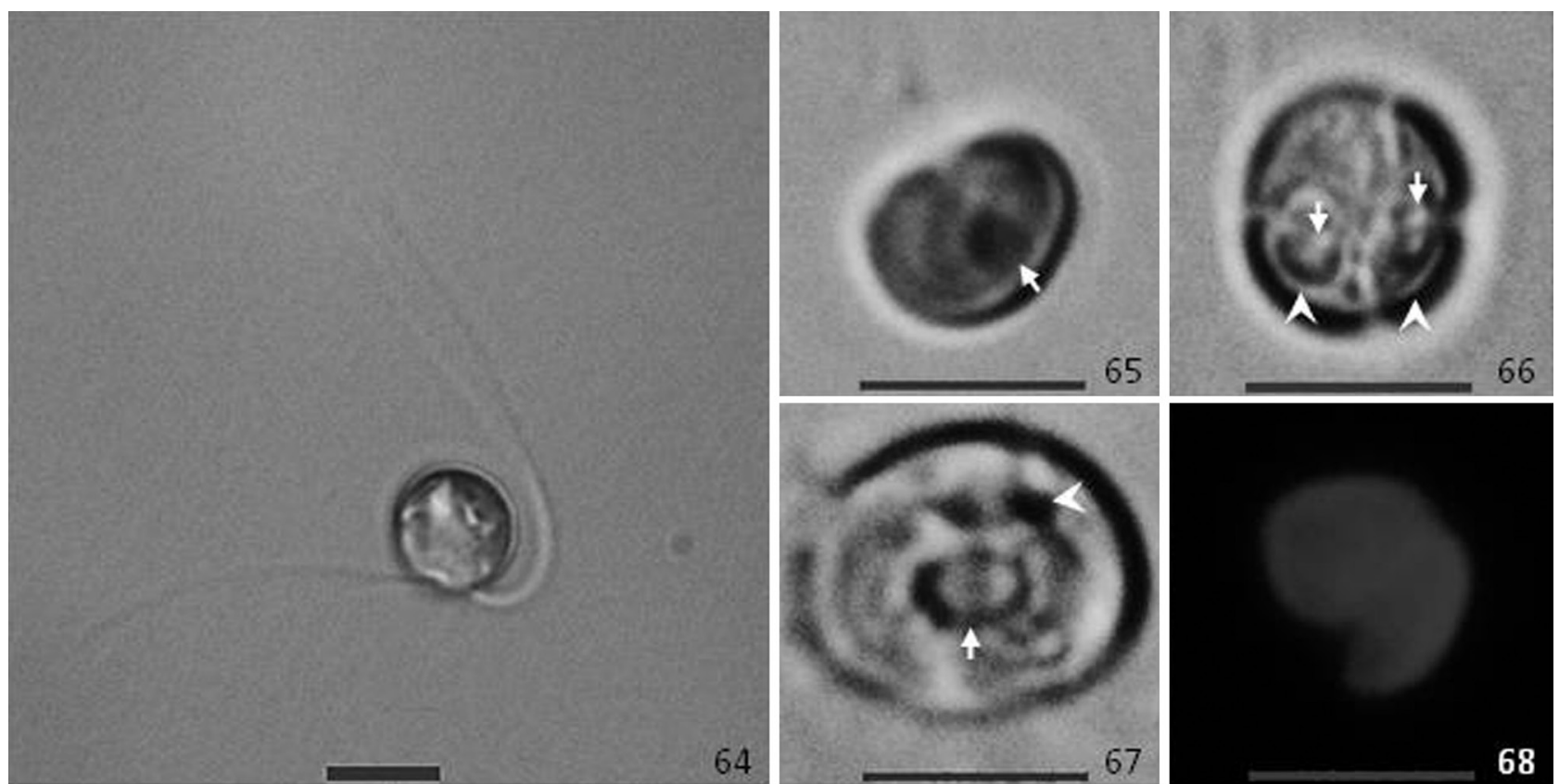

64
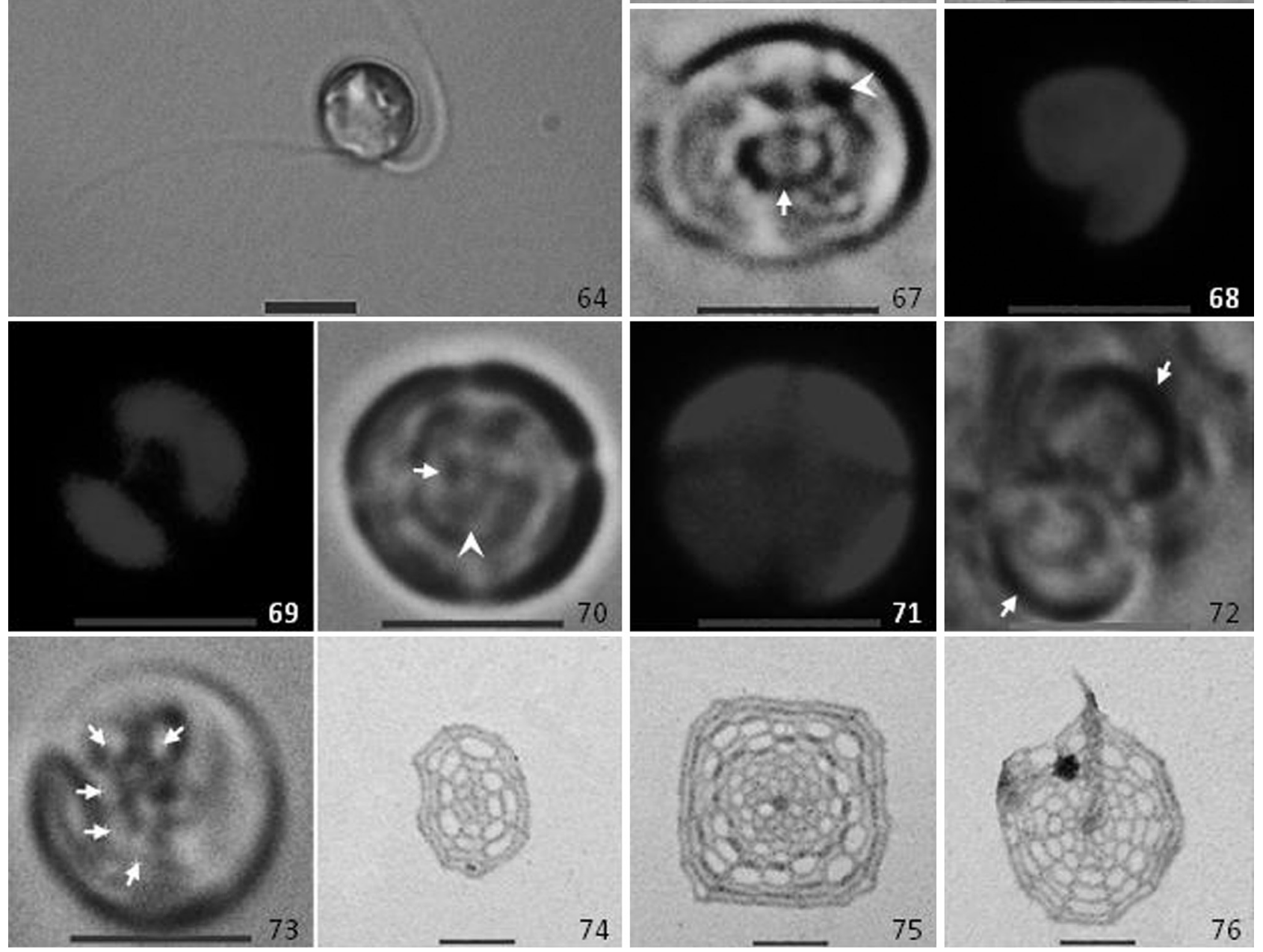

Figures 64-76 Cells and scales of Mamiella gilva, strain CGA06, from the Nervión River estuary, LM (64-73), TEM (74-76).

(64) Discoid cell with flagella in common swimming position. (65) Cell with the ventral side slightly lobed in which a rounded, basal pyrenoid (arrow) is clearly visible. (66) Ventral view of a dividing cell with duplicated pyrenoid (arrowheads) and pigmented bodies (arrows), possibly eyespots. (67) Ventral view of a cell showing a central oval pyrenoid (arrow) and a somewhat lateral eyespot (arrowhead). (68) Cell in epifluorescence showing two-lobed chloroplast with dorsal end toward top right corner. (69) Cell in epifluorescence showing a chloroplast in which one of the lobes splits into two toward the ventral end. (70) Cell in ventral view with a four-lobed chloroplast, a central pyrenoid (arrowhead), and an eyespot (arrow). (71) Cell in epifluorescence showing the four lobes of a chloroplast. (72) Dividing cell showing pyrenoids (arrows) covered by two cup-shaped grains. (73) Cell with cytoplasmic grains (arrows), possibly extrusomes. (74) Small body scale. (75) Large body scale. (76) Flagellar spiny scale. Scale bars: $5 \mu \mathrm{m}$ (Figures 64-71 and 73), $2.5 \mu \mathrm{m}$ (Figure 72), 100 nm (Figures 74-76).

11 to $29 \mu \mathrm{m}$ in length. In lateral view, cells were discoid with the ventral end more or less truncated (Figure 64), oblong or heart-shaped with slightly lobulated ventral end (Figure 65). In ventral view, cells were rounded, rectangular with rounded corners, or oval (Figures 66 and 67). The chloroplast was yellowish-green with a smooth texture and two main lobes that sometimes divided into two toward the ventral end of the cell (Figures 68-71). 
One or sometimes two yellowish eyespots were observed either on the dorsal side of the chloroplast or in the lobes, toward the ventral end and sometimes close to the pyrenoid region (Figures 66, 67, and 70). The pyrenoid was basal or centrally located (Figures 65, 67, and 70) and covered by two cupulate grains (Figure 72). A pair of pyrenoids was observed in possibly dividing cells (Figures 66 and 72). Some cells also showed two to five yellowish granules in the cytoplasmic space between the chloroplast lobes (Figure 73). Three types of scales, all with a cobweb design, were observed in strain CGA06. Small body scales had a more or less octagonal, oblong shape, resembling a rectangle with flattened corners (Figure 74, Table 2). Large body scales were more or less square in shape, sometimes with flattened corners, which made them somewhat octagonal (Figure 75, Table 2). Some of the flagellar scales were similar to small body scales and others were shaped like rounded hexagons: both had an adnate spine that served as one of their radial ribs (Figure 76, Table 2).

\section{Distribution}

Mamiella gilva has been previously recorded in the Nervión River estuary (Seoane et al. 2005), UK (Parke and Rayns 1964), Thailand, Denmark, and New Zealand (Moestrup 1984), Tasmania (LeRoi and Hallegraeff 2006), Australia (Hallegraeff et al. 2010), Eastern Canadian waters (Bérard-Therriault et al. 1999), Norway (Throndsen et al. 2007), and California (Thomsen and Buck 1998). Besides, strains of this monospecific genus have been recorded as Mamiella sp. in Japan (NIES Microbial Culture Collection, http://mcc.nies.go.jp/, strains NIES-2310 and NIES-2329) and Canada (Smith and Hobson 1994).

\section{Nephroselmis pyriformis (Carter) Ettl 1982 (Figures 77-85)}

\section{Synonyms}

Bipedinomonas pyriformis Carter, Anisomonas longifilis Butcher, Nephroselmis longifilis (Butcher) Norris, Anisonema longifilis (Butcher) Norris, Heteromastix longifilis (Butcher) Rayns.

\section{Morphology}

Cells were 3-6 $\mu \mathrm{m}$ long and 4-6 $\mu \mathrm{m}$ high in lateral view. The longer flagellum was 9-23 $\mu \mathrm{m}$ long and the shorter one 4-14 $\mu \mathrm{m}$ long. Cells varied in shape from elliptical or oval to round in lateral view (Figures 77 and 78). In anterior and posterior views, cells appeared laterally flattened with an oblong shape, more or less oval (Figure 79). The two-lobed chloroplast was dark or shiny, yellowish-green, with a smooth texture, and occasionally with lobes of unequal length (Figures 77 and 78). The single eyespot (only observed in strain CGA08) was yellow and located near the end of the anterior chloroplast lobe (Figure 78). The pyrenoid was located on the ventral side of the cell and was covered by a continuous starch sheath or an almost continuous, cup-shaped starch grain in strain CGA08 (Figure 78), while in strain CGA07, the sheath was composed of two cupulate starch grains (Figure 80). At least one greenish grain close to each chloroplast lobe was observed in some cells (Figure 80). Among the scales observed, small stellate scales (Figures 81-83, Table 2) were found to have different scale formulae in the strains analyzed (terminology from Bell 2008). In strain CGA07, scales were bipolar with a formula of $8: 1+1: 2 / 3$, and were 44-45 $\mathrm{nm}$ in height, from tip to tip of the polar spines, and $41-55 \mathrm{~nm}$ in diameter. The tips of the spines in these scales were blunt. However, the small stellate scales of strain CGA08 were unipolar with a formula of 9:1:2/4 and 37-50 $\mathrm{nm}$ in diameter. The T-hairs from the two strains differed in the number of distal subunits: $8-11$ in strain CGA07 and 14-15 in CGA08 (Figure 84, Table 2). The tip hairs of the two strains showed fragmented distal shaft regions that also differed in the number of segments of unequal length present (not shown): seven in strain CGA08 and eight in CGA07 (Figure 85, Table 2).

\section{Distribution}

Nephroselmis pyriformis may be considered a cosmopolitan species. Moestrup (1983) considered it as an eurythermic and euryhaline species present in coastal waters of England, Norway, Denmark, Iceland, Mexico, the USA, Thailand, and New Zealand. Its occurrence has been also reported from the coasts of California and Denmark (Thomsen and Buck 1998), Brazil (Bergesch et al. 2008), Norway and surrounding oceanic waters (Throndsen et al. 2007), Australia (Hallegraeff et al. 2010), Eastern Canadian waters (Bérard-Therriault et al. 1999), and Japan and Pacific Ocean waters (Nakayama et al. 2007).

\section{Phylogenetic analysis}

The three phylogenetic analyses (NJ, ML, and B) of the $18 \mathrm{~S}$ rRNA yielded similar topologies, with a consensus tree 


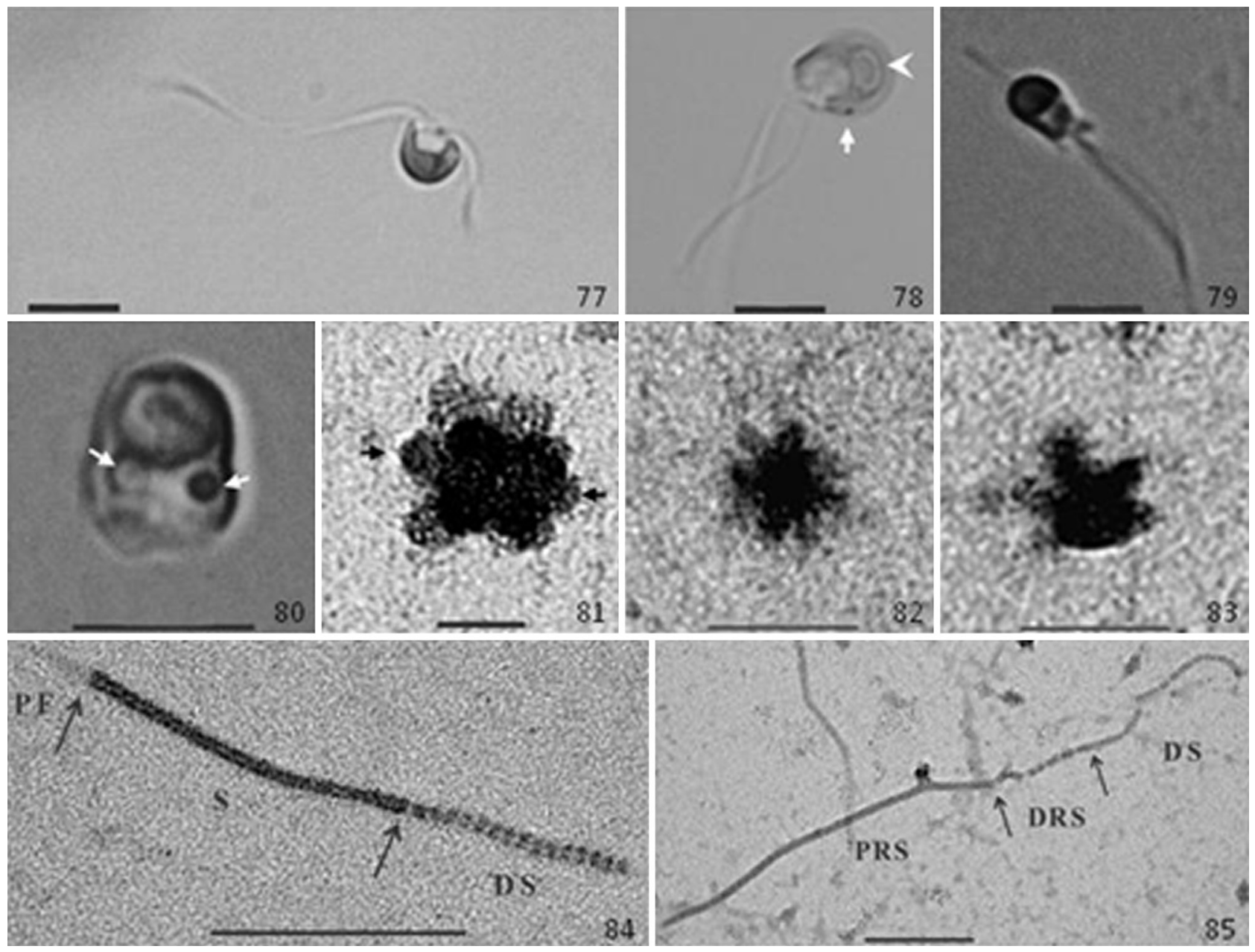

Figures 77-85 Cells and scales of Nephroselmis pyriformis from the Nervión River estuary, LM (77-80), TEM (81-85). (77) Left view of a swimming cell, strain CGA08. (78) Cell showing an elliptical pyrenoid (arrowhead) covered by an almost continuous, cup-shaped sheath, and an eyespot (arrow) in a chloroplast lobe, CGA08. (79) Anterior view of a cell, CGA08. (80) Cell showing cytoplasmic granules (arrows) between chloroplast lobes and pyrenoid cover composed of two grains, CGA07. (81) Lateral or slightly oblique view of a scale with two polar spines (arrows) extending toward left and right of the image, CGA07. (82 and 83) Distal and lateral view, respectively, of unipolar scales, CGA08. (84 and 85) T-hair and tip flagellar hair structure, respectively, delimited by regions (arrows) formed by the proximal filament (PF), the shaft (S), the distal subunits (DS), the proximal (PRS) and the distal (DRS) regions of the shaft, CGA08. Scale bars: $5 \mu \mathrm{m}$ (Figures 77-80), $200 \mathrm{~nm}$ (Figures 84 and 85), $50 \mathrm{~nm}$ (Figures 82 and 83), $20 \mathrm{~nm}$ (Figure 81).

presented in Figure 86. Three major clades were formed: the first clade corresponds to the genus Oltmannsiellopsis M. Chihara et I. Inouye as an outgroup (Ulvophyceae, Oltmannsiellopsidaceae); the second clade groups together Pyramimonas and Mamiella Moestrup; and the third clade encompasses the genus Nephroselmis F. Stein. All these clades were phylogenetically well supported with bootstrap (BT) values above 84, with the exception of the branch encompassing prasinophytes (second and third clades), which was not supported in the NJ analysis, and the Nephroselmis clade, which was not supported in the B analysis. The identity of Mamiella gilva (CGA06) and Nephroselmis pyriformis (CGA07, CGA08) agreed closely with the corresponding species from GenBank and appeared in the same branches of conspecific species supported by BT values of 100. Strains CGA17 and CGA19, corresponding to Oltmannsiellopsis unicellularis I. Inouye et M. Chihara, were located in the same branch of other Oltmannsiellopsis species, and appeared closer to Oltmannsiellopsis geminata I. Inouye et M. Chihara than to Oltmannsiellopsis viridis (P.E. Hargraves et R.L. Steele) $\mathrm{M}$. Chihara et I. Inouye sequences in all the phylogenetic trees constructed. The genus Pyramimonas was further divided into four subclades, containing species corresponding to the subgenera Punctatae (including, among others, Pyramimonas robusta, CGA15), Trichocystis 


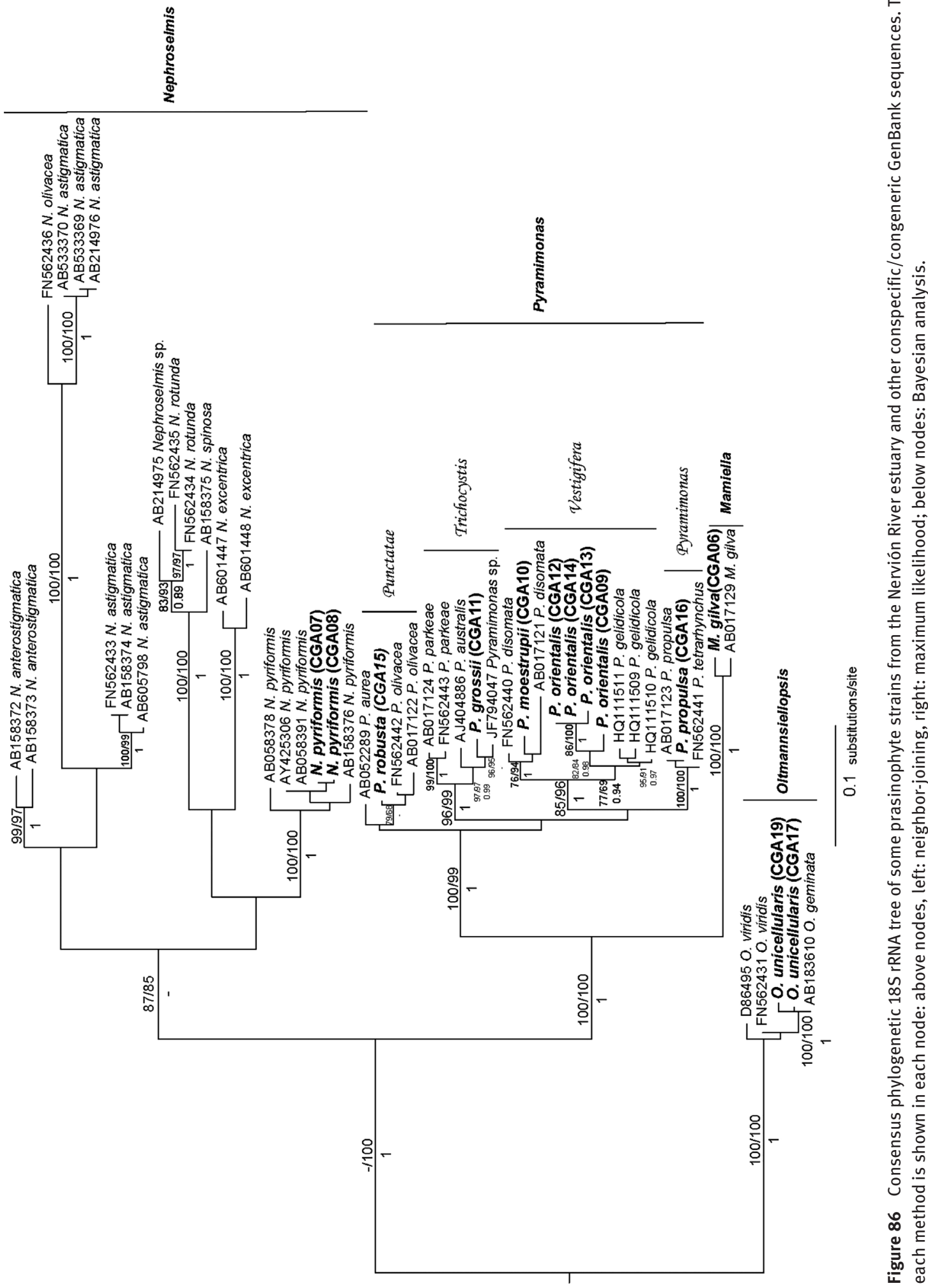


(Pyramimonas grossii, CGA11), Vestigifera (P. moestrupii, CGA10, and Pyramimonas orientalis, CGA09, CGA12-14), and Pyramimonas (Pyramimonas propulsa, CGA16). All the branches of the subgenera were relatively well supported with BT values above 84 and posterior probabilities of 1 , except the branch housing the Punctatae clade, which was not supported in any of the phylogenetic analyses used. On the other hand, the relationships between subgenera were not resolved in our analysis, which weakly supported the splitting of the branch of subgenus Punctatae and supported the branching of species analyzed in all other subgenera with BT values above 75 and posterior probabilities close to 1 . Finally, the branch within the Trichocystis clade that contains P. grossii (CGA11) was not supported by the B analysis.

\section{Pigment analysis}

Only two chlorophylls were detected, namely, $a$ and $b$, and were present in all the strains. Chlorophyll $b$ showed high ratios relative to chlorophyll $a$ with values between 0.45 and 0.6, which corresponded to Pyramimonas species (Table 3).

Among carotenoids, three different pigment patterns were observed. The first pattern, represented by Mamiella gilva, showed some pigments not observed in the rest of the strains such as uriolide, prasinoxanthin, and an unknown carotenoid. The second pigment pattern was shared by Pyramimonas grossii and Pyramimonas moestrupii, and was characterized by the presence of loroxanthin esters, and the third pigment pattern, found in Nephroselmis pyriformis, and the remaining species of Pyramimonas was the only one with siphonaxanthin esters (Table 3). Free siphonaxanthin was not detected in any of the species studied, but interestingly, free loroxanthin occurred not only in the loroxanthin ester-containing species but also in the siphonaxanthin ester-containg ones (except in Pyramimonas propulsa CGA16 and Pyramimonas orientalis CGA09). Although no further attempt was made to fully characterize the sterifying acid, the loroxanthin esters detected here coeluted with loroxanthin decenoate and loroxanthin dodecenoate previously isolated in several species of the genus Tetraselmis (Garrido et al. 2009), and the most abundant siphonaxanthin ester (with higher retention time) was indistinguishable in both retention and on-line spectrum from siphonaxanthin dodecenoate isolated from Codium fragile.

Regarding pigment ratios to chlorophyll $a$, the highest ratios in carotenoids in almost all the species were those of violaxanthin, with values between 0.16 and 0.61. However, the highest value was shown by $\beta \beta$ carotene (0.76) in P. orientalis (CGA09) (Table 3). The loroxanthin esters exhibited low ratios for chlorophyll $a$, while the siphonaxanthin esters, although they were normally between 0.1 and 0.2 , reached a maximum of 0.71 in P. orientalis (Table 3).

\section{Discussion}

\section{Morphological features}

The scale pattern of Pyramimonas orientalis agrees closely with previous observations (Pennick 1978, 1984, McFadden et al. 1986, Marin and Melkonian 1994, Pienaar and Sym 2002). However, some variability in the shape of box scales has been previously reported in some Pyramimonas species (McFadden et al. 1986, Daugbjerg and Moestrup 1992, 1993, Sym and Pienaar 1995, Daugbjerg 2000), so the presence in our strains of square and rectangular box scales, not only in P. orientalis but also in Pyramimonas grossii, Pyramimonas robusta, and Pyramimonas propulsa, may be explained by a dimorphism. Moestrup and Thomsen (1974, figure 6) have previously documented a similar dimorphism in $P$. orientalis, with no supportive statement, along with an unusual square body scale with eight small knobs. Another noteworthy characteristic of the strains analyzed is the presence of a tail or irregularly shaped posterior end in some cells. This tail, which may have red globules that could be confused with eyespots in LM, is a common feature of the subgenus Vestigifera according to Sym and Pienaar (1995). These globules correspond to vacuoles with a stellate or cruciform profile and electron-dense content (Sym and Pienaar 1995). In this study, none of these red globules were noted as such, but it is possible that, in those cases in which three eyespots were observed (strains CGA09 and CGA13), at least one could be such a globule, especially taking into account that the position of the eyespots for this species is described as mid-anterior (Butcher 1959, McFadden et al. 1986), and some of the pigmented bodies appeared at the posterior end of the cell. The morphology of the chloroplast, including a noticeable sinus, is another feature relating these strains with the subgenus Vestigifera and the species $P$. orientalis, in which one of the sinuses reaches the posterior end of the cell (Sym and Pienaar 1995). The presence of multilobed forms has not been mentioned before for this species: it has only been described for Pyramimonas gelidicola McFadden, Moestrup et Wetherbee (van den Hoff and Ferris 2009), Pyramimonas amylifera (Hargraves 


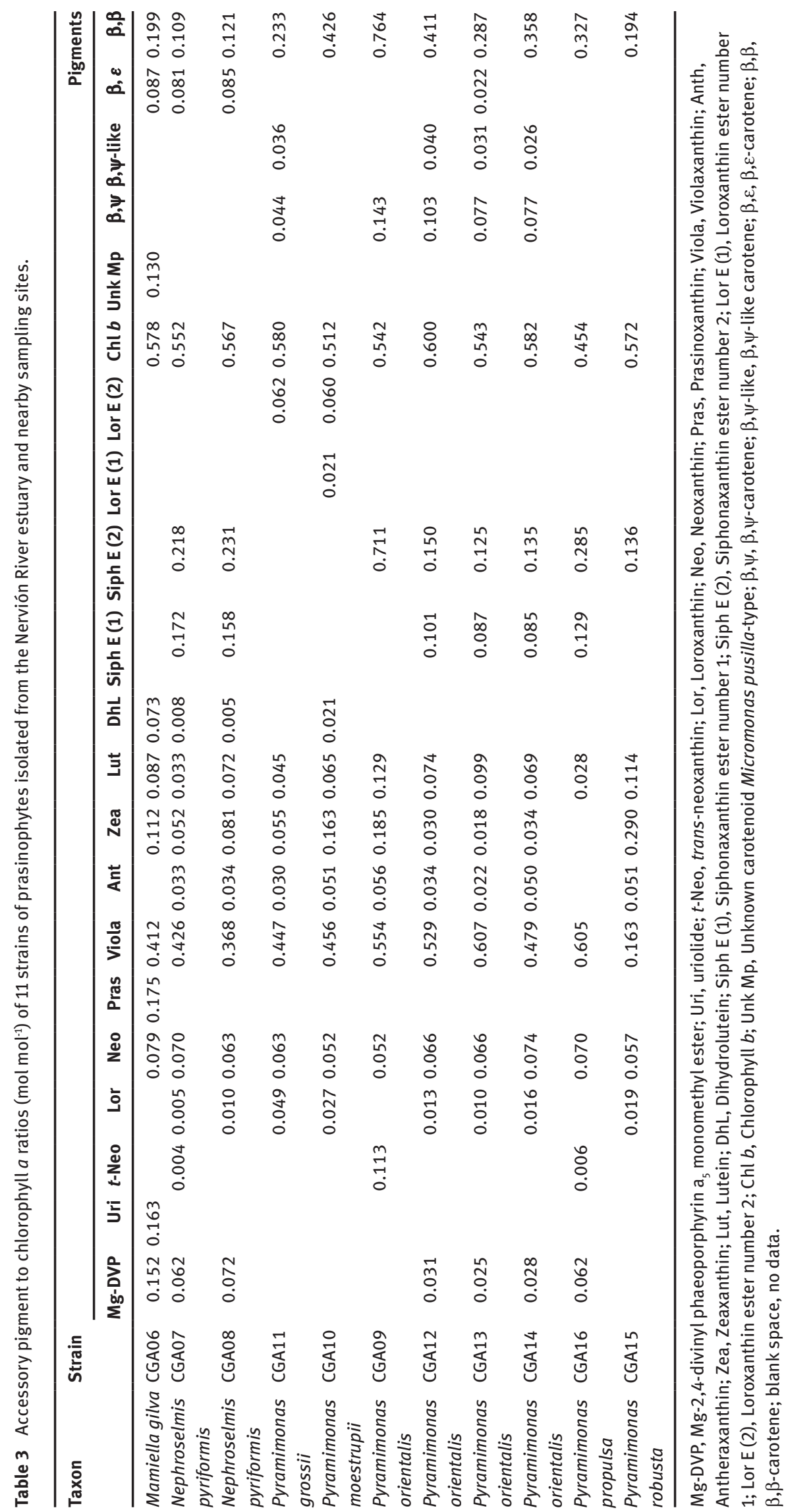


and Gardiner 1980) and Pyramimonas parkeae R.E. Norris et B.R. Pearson (Aken and Pienaar 1981).

The crown scales observed in Pyramimonas moestrupii were similar to those described for the type material (McFadden et al. 1986), but differed in size and shape from the original description of Pyramimonas norrisii (Sym and Pienaar 1991), which was subsequently considered synonymous with Pyramimonas moestrupii (Sym and Pienaar 1995). In particular, the curved uprights of the crown scales of strain CGA10 rise at, or near, the point where the bifurcation of the struts forming the basal cross begins (as in McFadden et al. 1986, figure 5), while in the algae described by Sym and Pienaar (1991), they rise from just above one of the spines found at the outer framework. On the other hand, the box scale morphology agrees with that reported previously (McFadden et al. 1986, Sym and Pienaar 1991, 1995). However, only Sym and Pienaar (1991) referred to the morphology of hair scales in this species, mentioning their size and disposition in relation to the rest of the flagellar scales, but saying nothing about a shaft divided into two regions or a possible distal filament, as shown in this study. In P. orientalis and other Vestigifera species, the presumed eyespots in the conspicuously nonlobed part of the chloroplast could correspond to pigmented globules because, when present, two eyespots are located in adjacent lobes, in particular, in P. moestrupii and other South African representatives, in which they appear toward the anterior part of the cell (S.D. Sym, personal communication, McFadden et al. 1986). Finally, the presence of multilobed forms has not been previously described for $P$. moestrupii.

The scales of $P$. grossii agreed well in shape and size with previous observations (Manton et al. 1963, McFadden et al. 1986, Sym and Pienaar 1993), except for some slight differences. For example, the crown scales differed from those shown in Pennick and Clarke (1976) and Pennick (1984), in which the large spines on each side of the basal framework are absent, while four struts forming a basal cross are present. Likewise, the limuloid scales described for strain CGA11 agreed with those in Sym and Pienaar (1993) but differed from those described in Pennick and Clarke (1976) and Pennick (1984), which only showed two perforations due probably to the use of shadowcasting, which could have hidden the smallest perforations. In addition, the T-hairs described for strain CGA11 are identical to those attributed to $P$. grossii by Marin and Melkonian (1994). On the other hand, the presence of five to six trichocysts per cell was described by Manton (1969) and Sym and Pienaar (1993), whereas in this study, up to eight granules were observed in the anterior part of living cells, at least some of them staining with DAPI in fixed cells, while numerous ejected trychocysts were found around single cells in TEM.

The maximum cell size of $P$. robusta was slightly greater than that given by Pienaar and Sym (1997) in the original description, but the morphology of the scales and the presence of puncta coincided. The average size of all scales observed was also somewhat greater than in the original description. Additional spines were observed on the corners of box scale walls and their base plates were apparently not perforated. For crown scales, the framework of their base is not as flat as represented in Pienaar and Sym (1997). Furthermore, the color of the eyespot in strain CGA15 is yellow, as opposed to orange-red in the original description (Pienaar and Sym 1997). In any case, all these differences lie within the limits of what can be considered as intraspecific variability.

In strain CGA16, the overall cell structure and scale morphology are typical of P. propulsa (Moestrup and Hill 1991, Sym and Pienaar 1997). Nevertheless, the length of the cells from this strain $(12-18 \mu \mathrm{m})$ was slightly less than that found in the original description, 17-21 $\mu \mathrm{m}$ (Moestrup and Hill 1991), but in any case, the size tends to vary from one strain to another for almost all species, especially in the genus Pyramimonas (Sym and Pienaar 1995). In contrast to Moestrup and Hill (1991), the starch sheath of the pyrenoid had four grains rather than many, and at least some cells have two eyespots instead of just one. These features were in agreement with Sym and Pienaar (1997), where strains of $P$. propulsa isolated from South Africa are described, most of which had two eyespots and a starch sheath composed of a few grains. The number and nature of the grains in the pyrenoid sheath is considered of little taxonomical importance, as it is a feature related to the development of the algae. Sym and Pienaar (1997) also mentioned the presence of small starch grains in the anterior part of the chloroplast lobes and osmophilic bodies close to the cell membrane resembling puncta, which coincides with the small grains or vesicles observed in the strain analyzed in this study. All these similarities suggest that the strain CGA16 belongs to the species P. propulsa.

Based on the general cell morphology and scales, it can be concluded that strain CGA06 belongs to Mamiella gilva (Parke and Rayns 1964, Moestrup 1984, LeRoi and Hallegraeff 2006) and that the yellowish granules observed are likely to be extrusomes as described by Moestrup (1984). Nevertheless, some discrepancies must be pointed out. On the one hand, the cells are somewhat larger than in the original description (Parke and Rayns 1964), and the only position described for the eyespot in $M$. gilva is at the dorsal end of the chloroplast (Moestrup 1984), while in strain CGA06, it sometimes appears 
in the lobes. Further analysis of the ultrastructure in thin sections would be required to confirm the variable position of the eyespot or the presence of a second one in some cells, in preparation for cell division. On the other hand, there are differences between the flagellar scales described above and those in the literature, e.g., a more or less octagonal shape instead of a clearly hexagonal one as stated by Parke and Rayns (1964). In any case, all these differences can be considered as intraspecific variation.

Nephroselmis pyriformis is the only species of the genus with a single layer of stellate scales, composed specifically of small stellate scales (Bell 2008, Faria et al. 2011, 2012, Yamaguchi et al. 2011). Owing to these characteristic scales and the reduced cell size, the strains from this study can all be attributed to N. pyriformis. However, the presence in the strains analyzed of various types of T-hair differing only in the number of distal subunits and the absence of a differentiated distal region in their shafts also fit with $N$. olivacea F. Stein (Marin and Melkonian 1994, Bell 2008). However, Nephroselmis olivacea is a freshwater species with little morphological similarity to $N$. pyriformis. On the other hand, the granules present in the cytoplasm could be lipid droplets. These droplets, although more related to Nephroselmis rotunda (N. Carter) Fott, could be related to ambient conditions. Moreover, the absence of an eyespot in strain CGA07 would seem to point to Nephroselmis astigmatica I. Inouye et R.N. Pienaar, but this species is considerably larger (9.0-13.5 $\mu \mathrm{m}$ long) and has larger stellate scales (Inouye and Pienaar 1984), so it can be discarded. Even so, it would be necessary to make thin sections of this strain to confirm the absence of an eyespot. Confirmation would mean that this would no longer be an exclusive characteristic of $N$. astigmatica .

\section{Phylogenetic relationships}

All the strains sequenced in this study have been closely related to $18 \mathrm{~S}$ rRNA sequences corresponding to conspecific or congeneric species found in GenBank with significant BT and posterior probability values. This means that, even if in some cases there is a lack of conspecific sequences to compare with (e.g., Oltmannsiellopsis unicellularis and all Pyramimonas species analyzed except Pyramimonas propulsa), the genetic analysis supports the morphological identification of all of them. Furthermore, the lack of congeneric sequences could explain the fact that the prasinophyte clade (Pyramimonas, Mamiella, and Nephroselmis species) was not supported in the NJ analysis, and the Nephroselmis clade was not supported in the Bayesian analysis. In spite of this, the phylogenetic tree topology constructed suggests the monophyly of all the traditional Pyramimonas subgenera (McFadden et al. 1986, 1987), with the exception of the subgenus Punctatae. As, from their analysis of the $r b c L$ gene, Daugbjerg et al. (1994) concluded that the four traditional subgenera described in Pyramimonas based on morphological characters were congruent with the phylogeny, other studies have expressed doubts concerning this position, as new species have been described, and phylogenies with more sequences, including $18 \mathrm{~S}$ rRNA based ones, have been built up (Moro et al. 2002, Suda 2004). Our results are in agreement with these more recent studies, which support monophyly for all traditional Pyramimonas subgenera, except for the Punctatae, and do not resolve the relationships between the subgenera. There has been a great deal of controversy around the subgenus Punctatae. While some authors hold that there are sufficient morphological similarities to consider subsuming Punctatae into the subgenus Pyramimonas (Sym and Pienaar 1999), others propose maintaining Pyramimonas olivacea N. Carter and Pyramimonas robusta in the Punctatae and moving all other species into two new subgenera: one including Pyramimonas formosa S.D. Sym et R.N. Pienaar and the other including Pyramimonas mucifera S.D. Sym et R.N. Pienaar and Pyramimonas aurea S. Suda (Suda 2004). This study supports the division of Pyramimonas into two branches: one with the Punctatae species and another with species belonging to the rest of the subgenera. Our result does not allow us to confirm either the monophyly of the subgenus or any further division between the Punctatae species, but it suggests that, despite morphological similarities with Pyramimonas, the subgenus Punctatae should remain independent at least until further phylogenetic analysis including more sequences and genes has been obtained.

\section{Pigment analysis}

According to the carotenoid composition, the prasinophyceans have traditionally been grouped into three pigment types: type 1 including neoxanthin, violaxanthin, lutein, zeaxanthin, and $\beta \beta$-carotene; type 2 , adding siphonaxanthin or loroxanthin and their esters; and type 3 including prasinoxanthin, uriolide, micromonol, micromonal, and dihydrolutein (Egeland et al. 1997). Our study detected species of type 3 (Mamiella gilva) and, above all, type 2. However, within type 2, it was possible to distinguish two different pigment patterns. In the first group (Pyramimonas grossii and Pyramimonas moestrupii), loroxanthin esters were present, and in the second (Nephroselmis 
pyriformis and remaining species of Pyramimonas), siphonaxanthin esters were present.

The presence of loroxanthin esters had been reported before in other prasinophyceans, such as Tetraselmis (Garrido et al. 2009), and the use of new HPLC methods is proving the existence of new pigments in this group. This is an argument for the reexamination of their pigment types.

For the strains of $P$. moestrupii (CGA10) and P. grossii (CGA11) analyzed in this study, the ratios of loroxanthin esters to chlorophyll $a$ were similar to those observed in species of the genus Tetraselmis and Pyramimonas parkeae, with values of $<0.1$ (Garrido et al. 2009). Furthermore, the values of the main pigment to chlorophyll $a$ ratios were also similar, with the highest of them being for violaxanthin, lutein, $\beta \beta$-carotene, and chlorophyll $b$ (Garrido et al. 2009). The values for the main pigments were higher compared with other genera of prasinophyceans (Latasa et al. 2004).

\section{Conclusion}

Scaly green nanophytoplankton from the Nervión River estuary and its surroundings show significant diversity taking into account the small scale of the study area (ca. $64 \mathrm{~km}^{2}$ ). In addition, although ultrastructural confirmation of some details observed by light microscopy remains pending, the strains analyzed show great variability in their morphological characteristics, especially among the species of Pyramimonas. In our opinion, this variability should be seen as representing morphological, adaptative plasticity inherent in dispersive life forms such as nanoplanktonic microalgae, and it highlights the need for careful, in-depth analysis of intraspecific variation to establish robust diagnostic, morphological characters for species identification. On the other hand, phylogenetic analysis has once again proven to be of great value in confirming the identity of isolated strains despite their morphological variability. Furthermore, even if our results do not resolve the relationships between Pyramimonas subgenera, they suggest that Punctatae should be maintained as an independent subgenus, at least until further analysis including more sequences and genes has been conducted. Finally, pigment data from this study, which includes algae belonging to the loroxanthin-containing prasinophytes, add useful information for the re-examination of pigment types in this group.

Acknowledgments: Alex Diez, Ricardo Andrade, and Jonh Arluzea helped in taking photographs with the electron microscope; Manuel Zapata, who, we are deeply sorry to say, passed away during this work, helped with the pigment analysis, a subject that he honored with his passionate research work throughout his career. Financial support for this research was provided by the Basque Government (project IT-481-10) and the Spanish Ministry of Economy and Competitiveness (projects CGL2010-19016 and GIC07/111-417-07) and the former Ministry of Education and Science (project CMT200604570/MAR). Grants from the University of the Basque Country (UPV/EHU) to H. David and from the Ministry of Education and Science to A. Alonso-González also supported this study. TEM work and genetic sequencing were performed in the unit of Analytical and High-Resolution Microscopy in Biomedicine, and the Sequencing and Genotyping Unit from SGIker services of the UPV/ EHU, respectively.

Funding: Spanish Ministry of Economy and Competitiveness, (Grant/Award Number: 'projects CGL2010-19016 and GIC07/111-417-07'), Spanish Ministry of Education and Science, (Grant/Award Number: 'CMT2006-04570/MAR'), University of the Basque Country (UPV/EHU).

\section{References}

Aken, M.E. and R.N. Pienaar. 1981. Observations on the reproduction of Pyramimonas parkeae Norris et Pearson (Prasinophyceae). S. Afr. J. Sci. 77: 330-331.

Bell, T.G. 2008. A taxonomic study of Nephroselmis Stein (Prasinophyceae, Chlorophyta). MSc Thesis, University of Witwatersrand, Johannesburg. pp. 149.

Bérard-Therriault, L., M. Poulin and L. Bossé. 1999. Guide d'identification du phytoplancton marin de l'estuaire et du golfe du Saint-Laurent incluant également certains protozoaires. Publ. Spéc. Can. Sci. Halieut. Aquat. 128: 1-387.

Bergesch, M., C. Odebrecht and $\varnothing$. Moestrup. 2008. Nanoflagellates from coastal waters of southern Brazil ( $\left.32^{\circ} \mathrm{S}\right)$. Bot. Mar. 51: 35-50.

Butcher, R.W. 1959. An introductory account of the smaller algae of British coastal waters. I. Introduction and Chlorophyceae. Fish. Invest. Lond. Ser. 4: 1-74.

Coleman, A.W. 1983. The use of fluorescence microscopy to study cell structure, nuclear ploidy, cell cycles and plastid DNA. In: (C.K. Tseng, ed) Proceedings of the joint US-China phycology symposium. Science Press, Beijing. pp. 291-310.

Daugbjerg, N. 2000. Pyramimonas tychotreta, sp. nov. (Prasinophyceae), a new marine species from Antarctica: light and electron microscopy of the motile stage and notes on growth rates. J. Phycol. 36: 160-171.

Daugbjerg, N. and $\varnothing$. Moestrup. 1992. Fine structure of Pyramimonas cyclotreta sp. nov. (Prasinophyceae) from Northern Foxe Basin, Arctic Canada, with some observations on growth rates. Eur. J. Protistol. 28: 288-298. 
Daugbjerg, N. and Ø. Moestrup. 1993. Four new species of Pyramimonas (Prasinophyceae) from arctic Canada including a light and electron microscopic description of Pyramimonas quadrifolia sp. nov. Eur. J. Phycol. 28: 3-16.

Daugbjerg, N., Ø. Moestrup and P. Arctander. 1994. Phylogeny of the genus Pyramimonas (Prasinophyceae, Chlorophyta) inferred from the $r b c$ Lene. J. Phycol. 30: 991-999.

Egeland, E.S., R.R.L. Guillard and S. Liaaen-Jensen. 1997. Additional carotenoid prototype representatives and a general chemosystematic evaluation of carotenoids in Prasinophyceae (Chlorophyta). Phytochemistry 44: 1087-1097.

Egeland, E.S., J.L. Garrido, L. Clementson, K. Andresen, C.S. Thomas, M. Zapata, R. Airs, C.A. Llewellyn, G.L. Newman, F. Rodríguez and S. Roy. 2011. Data sheets aiding identification of phytoplankton carotenoids and chlorophylls. In: (S. Roy, C.A. Llewellyn, E.S. Egeland and G. Johnsen, eds) Phytoplankton pigments: characterization, chemotaxonomy and applications in oceanography. Cambridge University Press, London. pp. 665-822.

Faria, D.G., A. Kato, M.R. de la Peña and S. Suda. 2011. Taxonomy and phylogeny of Nephroselmis clavistella sp. nov. (Nephroselmidophyceae, Chlorophyta). J. Phycol. 47: 1388-1396.

Faria, D.G., A. Kato and S. Suda. 2012. Nephroselmis excentrica sp. nov. (Nephroselmidophyceae, Chlorophyta) from Okinawajima, Japan. Phycologia 51: 271-282.

García-Barcina, J.M., J.A. González-Oreja and A. de la Sota. 2006. Assessing the improvement of the Bilbao estuary water quality in response to pollution abatement measures. Water Research 40: 951-960.

Garmendia, M., M. Revilla, J. Bald, J. Franco, A. Laza-Martínez, E. Orive, S. Seoane, V. Valencia and A. Borja. 2011. Phytoplankton communities and biomass size structure (fractionated chlorophyll "a"), along trophic gradients of the Basque coast (northern Spain). Biogeochemistry 106: 243-263.

Garrido, J.L., F. Rodríguez and M. Zapata. 2009. Occurrence of loroxanthin, loroxanthin decenoate, and loroxanthin dodecenoate in Tetraselmis species (Prasinophyceae, Chlorophyta). J. Phycol. 45: 366-374.

Granéli, E. and M.O. Moreira. 1990. Effects of river water of different origin on the growth of marine dinoflagellates and diatoms in laboratory cultures. J. Exp. Mar. Biol. Ecol. 136: 89-106.

Guillard, R.R.L. and J.H. Ryther. 1962. Studies of marine planktonic diatoms: I. Cyclotella nana Hustedt, and Detonula confervacea (Cleve) Gran. Can. J. Microbiol. 8: 229-239.

Hall, T.A. 1999. BioEdit: a user-friendly biological sequence alignment editor and analysis program for Windows 95/98/NT. Nucleic Acids Symp. Ser. 41: 95-98.

Hallegraeff, G.M., C.J.S. Bolch, D.R.A. Hill, I. Jameson, J.-M. LeRoi, A. McMinn, S. Murray, M.F. de Salas and K. Saunders. 2010. Algae of Australia: phytoplankton of temperate coastal waters. Australian Biological Resources Study, Canberra and CSIRO Publishing, Melbourne. pp. 432.

Hargraves, P.E. and W.E. Gardiner. 1980. The life history of Pyramimonas amylifera Conrad (Prasinophyceae). J. Plankton Res. 2: 99-108.

Ianson, D., S. Pond and T. Parsons. 2001. The spring phytoplankton bloom in the coastal temperate ocean: growth criteria and seeding from shallow embayments. J. Oceanogr. 57: 723-734.

Inouye, I. and T. Horiguchi. 1982. Notes on microalgae in Japan (6). Pyramimonas aff. amylifera Conrad (Prasinophyceae). Jap. J. Phycol. 30: 154.
Inouye, I. and R.N. Pienaar. 1984. Light and electron microscope observations on Nephroselmis astigmatica sp. nov. (Prasinophyceae). Nord. J. Bot. 4: 409-423.

Inouye, I., T. Hori and M. Chihara. 1985. Ultrastructural characters of Pyramimonas (Prasinophyceae) and their possible relevance in taxonomy. In: (H. Hara, ed) Origin and evolution of diversity in plants and plant communities. Academia Scientific Book Inc., Tokyo. pp. 314-327.

Katoh, K. and H. Toh. 2008. Recent developments in the MAFFT multiple sequence alignment program. Brief Bioinform. 9: 286-298.

Latasa, M., K. van Lenning, J.L. Garrido, R. Scharek, M. Estrada, F. Rodríguez and M. Zapata. 2001. Losses of chlorophylls and carotenoids in aqueous acetone and methanol extracts prepared for RPHPLC analysis of pigments. Chromatographia 53: 385-391.

Latasa, M., R. Scharek, F. Le Gall and L. Guillou. 2004. Pigment suites and taxonomic groups in Prasinophyceae. J. Phycol. 40: 1149-1155.

Laza-Martínez, A. 2012. Urgorri complanatus gen. et sp. nov. (Cryptophyceae), a red-tide-forming species in brackish waters. J. Phycol. 48: 423-435.

Laza-Martínez, A., S. Seoane, M. Zapata and E. Orive. 2007. Phytoplankton pigment patterns in a temperate estuary: from unialgal cultures to natural assemblages. J. Plankton Res. 29: 913-929.

Laza-Martínez, A., J. Arluzea, I. Miguel and E. Orive. 2012. Morphological and molecular characterization of Teleaulax gracilis sp. nov. and T. minuta sp. nov. (Cryptophyceae). Phycologia 51: 649-661.

LeRoi, J.-M. and G.M. Hallegraeff. 2006. Scale-bearing nanoflagellates from southern Tasmanian coastal waters, Australia. II. Species of Chrysophyceae (Chrysophyta), Prymnesiophyceae (Haptophyta, excluding Chrysochromulina) and Prasinophyceae (Chlorophyta). Bot. Mar. 49: 216-235.

Manton, I. 1969. Tubular trichocysts in a species of Pyramimonas (P. grossii Parke). Österr. Bot. Z. 116: 378-392.

Manton, I., K. Oates and M. Parke. 1963. Observations on the fine structure of the Pyramimonas stage of Halosphaera and preliminary observations on three species of Pyramimonas. J. Mar. Biol. Ass. UK 43: 225-238.

Marin, B. and M. Melkonian. 1994. Flagellar hairs in prasinophytes (Chlorophyta): ultrastructure and distribution on the flagellar surface. J. Phycol. 30: 659-678.

Marin, B. and M. Melkonian. 2010. Molecular phylogeny and classification of the Mamiellophyceae class. nov. (Chlorophyta) based on sequence comparisons of the nuclear- and plastidencoded rRNA operons. Protist 161: 304-336.

McFadden, G.I., Ø. Moestrup and R. Wetherbee. 1982. Pyramimonas gelidicola sp. nov. (Prasinophyceae), a new species isolated from Antarctic sea ice. Phycologia 21: 103-111.

McFadden, G.I., D.R.A. Hill and R. Wetherbee. 1986. A study of the genus Pyramimonas (Prasinophyceae) from southeastern Australia. Nord. J. Bot. 6: 209-234.

McFadden, G.I., D.R.A. Hill and R. Wetherbee. 1987. Electron microscopic observations on Pyramimonas olivacea N. Carter (Prasinophyceae, Chlorophyta). Phycologia 26: 322-327.

Moestrup, $\varnothing .1983$. Further studies on Nephroselmis and its allies (Prasinophyceae). I. The question of the genus Bipedinomonas. Nord. J. Bot. 3: 609-627. 
Moestrup, Ø. 1984. Further studies on Nephroselmis and its allies (Prasinophyceae). II. Mamiella gen. nov., Mamiellaceae fam. nov., Mamiellales ord. nov. Nord. J. Bot. 4: 109-121.

Moestrup, Ø. and D.R.A. Hill. 1991. Studies on the genus Pyramimonas (Prasinophyceae) from Australian and European waters: P. propulsa sp. nov. and P. mitra sp. nov. Phycologia 30: 534-546.

Moestrup, $\varnothing$. and H.A. Thomsen. 1974. An ultrastructural study of the flagellate Pyramimonas orientalis with particular emphasis on Golgi apparatus activity and the flagellar apparatus. Protoplasma 81: 247-269.

Moestrup, Ø., T. Hori and A. Kristiansen. 1987. Fine structure of Pyramimonas octopus sp. nov., an octoflagellated benthic species of Pyramimonas (Prasinophyceae), with some observations on its ecology. Nord. J. Bot. 7: 339-352.

Moro, I., N. La Rocca, L.D. Valle, E. Moschin, E. Negrisolo and C. Andreoli. 2002. Pyramimonas australis sp. nov. (Prasinophyceae, Chlorophyta) from Antarctica: fine structure and molecular phylogeny. Eur. J. Phycol. 37: 103-114.

Nakayama, T., S. Watanabe, K. Mitsui, H. Uchida and I. Inouye. 1996. The phylogenetic relationship between the Chlamydomonadales and Chlorococcales inferred from 18S rDNA sequence data. Phycol. Res. 44: 47-55.

Nakayama, T., S. Suda, M. Kawachi and I. Inouye. 2007. Phylogeny and ultrastructure of Nephroselmis and Pseudoscourfieldia (Chlorophyta), including the description of Nephroselmis anterostigmatica sp. nov. and a proposal for the Nephroselmidales ord. nov. Phycologia 46: 680-697.

Norris, R.E. 1964. Studies on phytoplankton in Wellington Harbour. N. Z. J. Bot. 2: 258-278.

Orive, E., J. Franco, I. Madariaga and M. Revilla. 2004. Bacterioplankton and phytoplankton communities. In: (A. Borja and M. Collins, eds) Oceanography and marine environment of the Basque Country. Elsevier, Amsterdam. pp. 367-393.

Orive, E., A. Laza-Martínez, S. Seoane, A. Alonso, R. Andrade and I. Miguel. 2010. Diversity of Pseudo-nitzschia in the southeastern Bay of Biscay. Diatom Res. 25: 125-145.

Parke, M. 1949. Studies on marine flagellates. J. Mar. Biol. Ass. UK 28: 255-288.

Parke, M. and D.G. Rayns. 1964. Studies on marine flagellates VII. Nephroselmis gilva sp. nov. and some allied forms. J. Mar. Biol. Ass. UK 44: 209-217.

Pennick, N.C. 1978. Studies on external morphology of Pyramimonas 5. P. amylifera Conrad. Arch. Protistenk. 120: 142-147.

Pennick, N.C. 1984. Comparative ultrastructure and occurrence of scales in Pyramimonas (Chlorophyta, Prasinophyceae). Arch. Protistenk. 128: 3-11.

Pennick, N.C. and K.J. Clarke. 1976. Studies on the external morphology of Pyramimonas 3. Pyramimonas grossii Parke. Arch. Protistenk. 118: 285-290.

Pienaar, R.N. 1978. The ultrastructure of the scale bearing flagellate Pyramimonas aff. amylifera Conrad (Prasinophyceae). Proc. S. Afr. Electron Microsc. Soc. 8: 75-76.

Pienaar, R.N. and S.D. Sym. 1997. Pyramimonas robusta sp. nov., a new punctate species, and a reappraisal of the subgenus Punctatae. Can. J. Bot. 75: 1965-1977.

Pienaar, R.N. and S.D. Sym. 2002. The genus Pyramimonas (Prasinophyceae) from southern African inshore waters. S. Afr. J. Bot. 68: 283-298.
Reize, I.B. and M. Melkonian. 1989. A new way to investigate living flagellated/ciliated cells in the light microscope: immobilization of cells in agarose. Bot. Acta 102: 145-151.

Ronquist, F. and J.P. Huelsenbeck. 2003. MrBayes 3: Bayesian phylogenetic inference under mixed models. Bioinformatics 19: 1572-1574.

Seoane, S., A. Laza, I. Urrutxurtu and E. Orive. 2005. Phytoplankton assemblages and their dominant pigments in the Nervion River estuary. Hydrobiologia 549: 1-13.

Seoane, S., A. Laza and E. Orive. 2006. Monitoring phytoplankton assemblages in estuarine waters: The application of pigment analysis and microscopy to size-fractionated samples. Estuar. Coast. Shelf Sci. 67: 343-354.

Seoane, S., M. Zapata and E. Orive. 2009a. Growth rates and pigment patterns of haptophytes isolated from estuarine waters. J. Sea Res. 62: 286-294.

Seoane, S., W. Eikrem, J. Arluzea and E. Orive. 2009b. Haptophytes of the Nervión River estuary, northern Spain. Bot. Mar. 52: 47-59.

Seoane, S., W. Eikrem, R. Pienaar and B. Edvardsen. 2009c. Chrysochromulina palpebralis sp. nov. (Prymnesiophyceae): a haptophyte, possessing two alternative morphologies. Phycologia 48: 165-176.

Smith, P.J. and L.A. Hobson. 1994. Temporal variation in taxonomic composition of flagellated nanoplankton in a temperate fjord. J. Phycol. 30: 369-375.

Stamatakis, A. 2006. RAxML-VI-HPC: maximum likelihood-based phylogenetic analyses with thousands of taxa and mixed models. Bioinformatics 22: 2688-2690.

Suda, S. 2003. Light microscopy and electron microscopy of Nephroselmis spinosa sp. nov. (Prasinophyceae, Chlorophyta). J. Phycol. 39: 590-599.

Suda, S. 2004. Taxonomic characterization of Pyramimonas aurea sp. nov. (Prasinophyceae, Chlorophyta). Phycologia 43: 682-692.

Sym, S.D. and R.N. Pienaar. 1991. Ultrastructure of Pyramimonas norrisii sp. nov. Br. Phycol. J. 26: 51-66.

Sym, S.D. and R.N. Pienaar. 1993. Further observations on Trichocystis, a subgenus of Pyramimonas (Prasinophyceae, Chlorophyta). Phycologia 32: 338-350.

Sym, S.D. and R.N. Pienaar. 1995. Taxonomy of Pyramimonas obovata and other observations on the subgenus Vestigifera of Pyramimonas (Prasinophyceae, Chlorophyta). Phycol. Res. 43: $17-32$.

Sym, S.D. and R.N. Pienaar. 1997. Further observations on the type subgenus of Pyramimonas (Prasinophyceae), with particular reference to a new species, $P$. chlorina, and the flagellar apparatus of $P$. propulsa. Can. J. Bot. 75: 2196-2215.

Sym, S.D. and R.N. Pienaar. 1999. An additional punctate species of Pyramimonas, $P$. formosa, sp. nov., and its impact on the subgenera Punctatae and Pyramimonas (Prasinophyceae, Chlorophyta). J. Phycol. 35: 1313-1321.

Tamura, K., D. Peterson, N. Peterson, G. Stecher, M. Nei and S. Kumar. 2011. MEGA5: molecular evolutionary genetics analysis using maximum likelihood, evolutionary distance, and maximum parsimony methods. Mol. Biol. Evol. 28: 2731-2739.

Thomsen, H.A. and K.R. Buck. 1998. Nanoflagellates of the central California waters: taxonomy, biogeography and abundances of primitive, green flagellates (Pedinophyceae, Prasinophyceae). Deep-Sea Res. // 45: 1687-1707. 
Throndsen, J. 1978. The dilution culture method. In: (A. Sournia, ed) Phytoplankton manual. UNESCO Monographs on Oceanographic Methodology 6. Unesco, Paris. pp. 218-224.

Throndsen, J., G.R. Hasle and K. Tangen. 2007. Phytoplankton of Norwegian coastal waters. Almater Forlag AS, Oslo. pp. 343.

van den Hoff, J. and J.M. Ferris. 2009. Pleomorphism in the Antarctic flagellate Pyramimonas gelidicola (Prasinophyceae, Chlorophyta). Polar Res. 28: 426-432.

Yamaguchi, H., S. Suda, T. Nakayama, R.N. Pienaar, M. Chihara and I. Inouye. 2011. Taxonomy of Nephroselmis viridis sp. nov.
(Nephroselmidophyceae, Chlorophyta), a sister marine species to freshwater N. olivacea. J. Plant Res. 24: 49-62.

Zapata, M. and J.L. Garrido. 1991. Influence of injection conditions in reversed-phase high-performance liquid chromatography of chlorophylls and carotenoids. Chromatographia 31: 589-594.

Zapata, M., F. Rodríguez and J.L. Garrido. 2000. Separation of chlorophylls and carotenoids from marine phytoplankton: a new HPLC method using a reversed phase $\mathrm{C}_{8}$ column and pyridine-containing mobile phases. Mar. Ecol. Prog. Ser. 195: 29-45. 